\title{
The Wiskott-Aldrich syndrome: The actin cytoskeleton and immune cell function
}

\author{
Michael P. Blundell ${ }^{\mathrm{a}}$, Austen Worth ${ }^{\mathrm{a}, \mathrm{b}}$, Gerben Bouma ${ }^{\mathrm{a}}$ and Adrian J. Thrasher ${ }^{\mathrm{a}, \mathrm{b}, *}$ \\ ${ }^{a}$ Molecular Immunology Unit, UCL Institute of Child Health, London, UK \\ ${ }^{\mathrm{b}}$ Department of Immunology, Great Ormond Street Hospital NHS Trust, Great Ormond Street, London, UK
}

\begin{abstract}
Wiskott-Aldrich syndrome (WAS) is a rare X-linked recessive primary immunodeficiency characterised by immune dysregulation, microthrombocytopaenia, eczema and lymphoid malignancies. Mutations in the WAS gene can lead to distinct syndrome variations which largely, although not exclusively, depend upon the mutation. Premature termination and deletions abrogate Wiskott-Aldrich syndrome protein (WASp) expression and lead to severe disease (WAS). Missense mutations usually result in reduced protein expression and the phenotypically milder X-linked thrombocytopenia (XLT) or attenuated WAS [1-3]. More recently however novel activating mutations have been described that give rise to X-linked neutropenia (XLN), a third syndrome defined by neutropenia with variable myelodysplasia [4-6]. WASP is key in transducing signals from the cell surface to the actin cytoskeleton, and a lack of WASp results in cytoskeletal defects that compromise multiple aspects of normal cellular activity including proliferation, phagocytosis, immune synapse formation, adhesion and directed migration.
\end{abstract}

Keywords: Wiskott-Aldrich syndrome, actin polymerization, lymphocytes, dendritic cells, migration, cell activation, immune cell function

\section{Abbreviations}

AGM: Aorto-gonad-mesonephros

ARPC: aActin related protein complex component

CRIB: Cdc42/Rac interactive binding

DC: $\quad$ Dendritic cells

EVH1: Ena-VASP homology domain 1

FRET: Fluorescence Resonance Energy Transfer

GBD: GTPase binding domain

GEF: Guanine exchange factor

IS: Immune synapse

MZB: Marginal zone B cells

N-WASp: Neuronal WASp

PH: $\quad$ Pleckstrin homology

$\mathrm{PIP}_{2}$ : $\quad$ Phosphatidylinositol (4,5)-bisphosphate

PLC $\gamma$ : Phospholipase C gamma

PSTPIP: Proline, serine threonine-rich phosphatase interacting protein

* Corresponding author: Adrian J. Thrasher, UCL Institute of Child Health, Molecular Immunology Unit, 30 Guilford Street, London, WC1N 1EH, UK. Tel.: +44 (0)20 7905 2289; Fax: +44 (0)20 7905 2810; E-mail: a.thrasher@ich.ucl.ac.uk.

\author{
SNX9: $\quad$ Sorting nexin 9 \\ TCR: $\quad$ T cell receptor \\ Toca-1: $\quad$ Transducer of Cdc42-dependent actin assembly-1 \\ Treg: $\quad$ Regulatory $\mathrm{T}$ cell \\ VCA: Verprolin homology, central and acidic regions \\ WAS: Wiskott-Aldrich syndrome \\ WAS KO: WAS knockout \\ WASH: WASp and SCAR homolog \\ WASp: WAS protein \\ WAVE: $\quad$ WASp family verprolin-homologous protein \\ WHAMM: WASP homolog associated with actin, membranes, \\ and microtubules \\ WIP: WASp interacting protein \\ XLN: $\quad$ X-linked neutropenia \\ XLT: $\quad \mathrm{X}$ - linked thrombocytopenia
}

\section{Introduction}

Wiskott-Aldrich syndrome (WAS) is a rare $\mathrm{X}$ linked recessive primary immunodeficiency characterised by immune dysregulation, microthrombocytopaenia, eczema and lymphoid malignancies. $\mathrm{Mu}-$ tations in the WAS gene can lead to distinct syndrome variations which largely, although not exclusively, depend upon the mutation. Premature termina- 
tion and deletions abrogate Wiskott-Aldrich syndrome protein (WASp) expression and lead to severe disease (WAS). Missense mutations usually result in reduced protein expression and the phenotypically milder Xlinked thrombocytopenia (XLT) or attenuated WAS [13]. More recently however novel activating mutations have been described that give rise to X-linked neutropenia (XLN), a third syndrome defined by neutropenia with variable myelodysplasia [4-6]. WASP is key in transducing signals from the cell surface to the actin cytoskeleton, and a lack of WASp results in cytoskeletal defects that compromise multiple aspects of normal cellular activity including proliferation, phagocytosis, immune synapse formation, adhesion and directed migration.

\section{Molecular structure}

WASp is a multidomain protein that lacks intrinsic catalytic activity. It acts as an adaptor to bring together downstream mediators that facilitate Arp2/3mediated actin polymerization. WASp consists of an N-terminal Ena-VASP homology domain 1 (EVH1), a basic domain, a GTPase binding domain (GBD), polyproline domain and the $\mathrm{C}$-terminal domain comprising of a cluster of verprolin homology (V), central (C) and acidic regions (A) (the VCA domain) (Fig. 1). WASp was the first member of a family of proteins that shares the ability to regulate Arp2/3 activity through their VCA domains. The other mammalian members (Fig. 1) that share expression of the VCA domain include neural WASp (N-WASp), WASp family verprolin-homologous protein (WAVE) 1-3 and the more recently discovered Wiskott-Aldrich syndrome protein and SCAR homolog (WASH) and WASP homolog associated with actin, membranes, and microtubules (WHAMM) [7-9]. Many studies have investigated isolated protein domains to gain insight into the function of WASp family members and have extrapolated findings of one member to predict function of another. In particular, studies of N-WASp have been used to predict function of WASp. The overall protein sequence identity between WASp and N-WASp is around $50 \%$, although sequence of the functional domain is much higher. Importantly, however, expression of WASp is restricted to haematopoietic cells while $\mathrm{N}-$ WASp is ubiquitously expressed $[10,11]$.

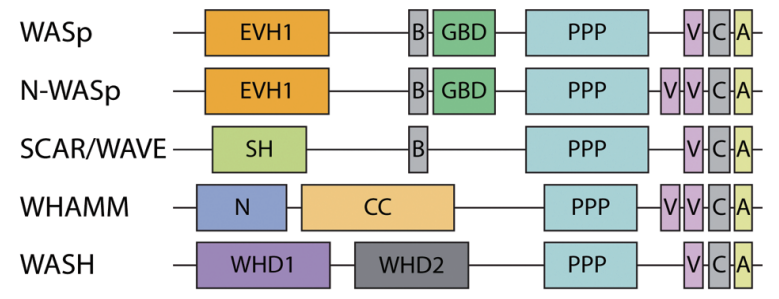

Fig. 1. Domain structure of WASp family protein members. Schematic representation of the protein domains of individual members of the WASp family. The $\mathrm{C}$ terminus, which is critical for regulation of actin polymerization, is highly conserved between the members, while the $\mathrm{N}$ terminus is divergent. EVH1, Ena Vasp homology domain; B, basic domain; GBD, GTPase binding domain; PPP, polyproline domain; V, verprolin homology domain; $\mathrm{C}$, central domain; A, acidic domain; SH, Scar homology domain; N, $\mathrm{N}$-terminal domain with insignificant homology to known protein; CC, coiled-coils domain; WHD1/2, WASH homology domain 1 and 2.

\section{EVH1 and WIP}

The EVH1 domain is a proline-rich region that has been implicated in actin remodelling. This domain is found in actin scaffold proteins, such as Mena, VASP and Evl. The best characterised EVH1 domain binding partners are members of the verprolin family of proteins. These include WASp-interacting protein (WIP), CR16 and WICH (WIP and CR16 homologous protein, also referred to as WIRE) [12]. Of these, WIP is probably the best characterized. It is a 503-amino acid long proline-rich protein, which is expressed in many tissues although most abundantly in haematopoietic cells [13]. While CR16 is known to be able to bind the WASp EVH1 domain, it is not expressed in haematopoietic cells; therefore, CR16/WASp interactions are not likely to be physiologically relevant [14]. WICH shows some ability to bind WASp, but this binding is much weaker compared to N-WASp binding. WICH is expressed at much lower levels in haematopoietic tissues compared to brain and gastrointestinal tissues, suggesting that $\mathrm{N}$ WASp is the preferred binding partner to WICH [15].

Amino acids 416-488 of WIP were initially identified as being required for WASp binding [16]. The crystal structure of WIP bound to the EVH1 domain of N-WASp shows that a 25 amino acid fragment (aa 461485 ) is minimally required for high affinity N-WASp binding [17]. Later the same group showed that for optimal binding, a larger sequence of WIP (aa 451485) wraps around the EVH1 domain of N-WASp; they also identified three WIP epitopes that are involved in WIP/N-WASp binding [18]. Many studies have used N-WASp to study the interaction of WASp with WIP. It is likely that these interactions are similar, but that 
the WIP/WASp interaction is more relevant in vivo given the similar tissue expression profiles. WIP inhibits N-WASp-mediated activation of Arp2/3 by direct interaction with N-WASp [19], and WIP maintains the autoinhibitory conformation of WASP in vivo [20]. A similar inhibitory mechanism exists for N-WASp, in which the WIP/N-WASp complex cannot initiate actin polymerization whereas free N-WASp can induce actin polymerization [21]. Toca-1 (transducer of Cdc42dependent actin assembly) could release WIP binding, enabling $\mathrm{Cdc} 42$ to activate the protein and initiate actin polymerization [21].

Compelling evidence that WIP binding is important for WASp expression was provided by several groups who have shown that when WIP is absent, no or very low levels of WASp expression can be detected [2224]. Furthermore, reduced levels of WASp expression in lymphocytes occur in WAS patients who carry mutations that abrogate WIP binding [23]. Interestingly, the majority of missense WASp mutations that give rise to clinical disease are located in the EVH1 domain. Several of these mutations (e.g. T45M, V75M, R86H, $\mathrm{Y} 107 \mathrm{C}$ and $\mathrm{A} 134 \mathrm{~T}$ ) result in reduced binding affinity for WIP [17,25,26] and are associated with reduced WASp expression, but normal mRNA levels. These observations suggest that WASp levels are low due to proteolysis as a consequence of altered WIP binding [1, $3,27,28]$. WASp expression in lymphocytes of these patients could be partially restored by proteasome inhibition [23]. Together this evidence strongly suggests a role for WIP in protecting WASp from degradation. While N-WASp degradation appears mediated by ubiquitination [29], WASp degradation seems a complex mechanism, which may be dependent on phosphorylation or activation state. WASp degradation can be inhibited either by blocking the proteasome in unstimulated human and murine T cells [23] and murine splenocytes [30], or by blocking calpain proteases in stimulated human platelets $[31,32]$, stimulated human T cells [23] and GM-CSF/TGF- $\beta$-cultured splenic murine dendritic cells (DC) [22]. An attractive hypothesis is that the proteasome is responsible for background turnover of WASp degradation and that calpain proteases are responsible for WASp degradation in response to activation and cell surface signalling, but further mechanistic investigation is required.

In addition, WIP binding mediates recruitment of WASp to podosomes [22,33], the phagocytic cup [34] and to the $\mathrm{T}$ cell receptor signalling complex after $\mathrm{T}$ cell stimulation $[23,35,36]$. Similarly, WIP binding to NWASp is required for the actin-based intracellular mo- bility of vaccinia virus [37]. These observations suggest that by binding to WASp, WIP prevents degradation of WASp, keeps it in an inactive state and helps to achieve correct subcellular localization, thus providing an important spatial and temporal regulation of WASp activity.

\section{Basic domain and PIP 2}

The basic domain is found in all members of the WASp family, although the specific sequence is poorly conserved. In WASp, the basic domain consists of 10 amino acids, of which six are lysine residues. The basic domain of N-WASp binds phosphatidylinositol (4,5)-bisphosphate $\left(\mathrm{PIP}_{2}\right)$ in vitro $[38,39]$. WASp can also bind $\mathrm{PIP}_{2}$, but the specific binding site remains unclear. Higgs and Pollard reported that a region encompassing the basic and GBD domains did not bind $\mathrm{PIP}_{2}$, in contrast to full length WASp [40]. Others have suggested that an N-terminal pleckstrin homology (PH) domain in WASp or N-WASp is responsible for $\mathrm{PIP}_{2}$ binding $[11,41]$. However, the sequence of such a $\mathrm{PH}$ domain shows weak alignment with the consensus PH domain sequence and overlaps with the EVH1 domain, raising the question whether this domain should be called a PH domain [42]. Despite low sequence homology, $\mathrm{PIP}_{2}$ binding and membrane localization were demonstrated for both WASp and N-WASp $[11,41,43]$. When the clinical $\mathrm{C} 43 \mathrm{~W}$ mutation was introduced into a truncated GST-WASp construct that contains the proposed $\mathrm{PH}$ domain, $\mathrm{PIP}_{2}$ binding was diminished. This observation suggests functionality of the $\mathrm{PH}$ domain [41], although it should be noted that the C43W mutation likely affects binding of WIP as well [44]. Binding to WIP is important for N-WASp sub cellular localization, and the corresponding C35W mutation in N-WASp abolished WIP-dependent recruitment of $\mathrm{N}-\mathrm{WASp}$ to intracellular vaccinia virus [37].

Deletion of the basic domain of N-WASp diminished the ability of N-WASp to induce actin-driven motility of coated beads and actin polymerization in cell lysates. By contrast, activity in a purified protein system containing Arp2/3 complex and monomeric actin was increased, suggesting that additional binding partners mediate the basic domain regulation of N-WASp activity [45]. One of these binding partners is likely to be $\mathrm{Cdc} 42$. Positively charged residues of the basic domain contribute to $\mathrm{Cdc} 42$ binding, through an electrostatic steering mechanism that mediates active $\mathrm{Cdc} 42$ to bind the GBD domain [46]. In addition, the ba- 
sic domain of N-WASp can bind the Arp2/3 complex, probably by contributing to the closed, autoinhibitory conformation of cytosolic N-WASp. $\mathrm{PIP}_{2}$ binding could release this binding, enabling full activation by Cdc42 [38]. Whether this is also the case for WASp remains to be investigated.

\section{GBD and activation by Cdc42 and phosphorylation}

The GTPase binding domain (GBD), which spans from residue 235 to 288 in WASp, can bind $\mathrm{Cdc} 42$ and to a lesser degree Rac1 [12,47-49]. Contained within the GBD is the Cdc42/Rac interactive binding (CRIB) domain, a highly conserved sequence of 14 amino acid residues found in Rho type GTPase binding proteins [50,51]. The affinity of GTP-bound Cdc42 to WASp is at least 500-fold higher compared to the GDP-bound form [48] and its binding is important for WASp activation.

A second important binding partner of the GBD is the intrinsic WASp VCA domain. In its native, inactive state, residues 482-492 within the VCA domain bind to residues 242-310 at the carboxyl end of the GBD, as well as the adjacent sequence between GBD and the polyproline domain [52,53]. This intramolecular binding, which has also been observed for N-WASp [39], inhibits the binding of Arp2/3 to the VCA domain, thereby keeping the protein in an inactive, autoinhibited conformation that prevents actin polymerization. In vivo studies confirmed the autoinhibited conformation of WASp and N-WASp using Fluorescence Resonance Energy Transfer (FRET) techniques [20,54] and are facilitated by a recently developed antibody that specifically recognizes the open conformation $[55,56]$. Tyrosine residue 291, within the GBD (aa 256 in N-WASp), is thought to be important in stabilising the open molecular conformation. Y291 can be phosphorylated by a variety of kinases from the Src and Tec kinase families. Although the ability to induce Arp2/3-mediated actin polymerization increases upon phosphorylation, more potent actin polymerization is observed when either GTP-Cdc42 or SH2 and SH3-domain-containing proteins are bound. Full potential activity is achieved when Cdc42 and SH2/SH3 binding act synergistically on phosphorylated WASp [57]. A model has been proposed in which GTP-Cdc42 disrupts the autoinhibited conformation of WASp, allowing Y291 to be phosphorylated; this stabilises the opened molecular confirmation and enables maximum actin polymerization [52,
53,57-59]. Other studies, however, have shown that partial deletion of the GBD (but not Y291) and consequently loss of GTP-Cdc42 binding, does not affect WASp activity, suggesting phosphorylation as an alternative Cdc42-independent mechanism of WASp activation $[60,61]$.

Phosphorylation of WASp is important for many cell processes including TCR signalling, filopodia and podosome formation, migration and phagocytosis, and appears to be a key regulatory mechanism of WASp activation. Phosphorylation of N-WASp is thought to regulate protein activation in a similar fashion. Several studies have examined the importance of phosphorylation by mutating the WASp Y291 to a 'phosphodead' phenylalanine (Y291F) or to a phospho-mimetic glutamic acid (Y291E). While variability exists depending on the experimental system, expression of WASp Y291F reduces the ability of WASp to induce actin polymerization and formation of phagocytic cups, filopodia or podosomes $[34,56,60,62]$. FRET showed that the autoinhibited molecular conformation of WASp Y291F is disrupted by $\mathrm{Cdc} 42$ activation, suggesting phosphorylation is not required for WASp activation, although the actin polymerization ability was not investigated [56]. Recently, knock-in mice were generated to express the murine equivalent (Y293F) of the human Y291F WASp mutant. These mice show a strikingly similar cellular phenotype to WASp deficient mice including reduced actin polymerization, podosome formation, migration and phagocytosis [30]. In contrast, introducing the phospho-mimetic Y291E showed normal cellular and protein function in some experimental systems, but enhanced actin polymerization and formation of filopodia and podosome structures in other systems $[34,56,62]$. Interestingly, mice expressing the phospho-mimetic Y293E phenotypically resemble WASp deficient animals due to decreased protein expression levels, which could be partly restored by inhibition of the proteasome [30]. Phosphorylation of Y256 by kinases such as Arg [63] is predicted to stabilise the 'opened' molecular conformation of N-WASp. Experiments using Y256 N-WASp mutants indeed show enhanced actin polymerization with a phospho-mimetic Y256E and reduced actin polymerization with a 'phospho-dead' Y256F mutant [64].

\section{Polyproline domain}

The polyproline domain is the largest of the functional domains of WASp. It contains multiple binding 
Table 1

WASp polyproline domain binding partners

\begin{tabular}{|c|c|c|}
\hline Partner & Known function & References \\
\hline \multicolumn{3}{|c|}{ Tyrosine kinases } \\
\hline Btk & Binds and phosphorylates WASp. & {$[62,67,70-72]$} \\
\hline Hck & Binds and phosphorylates WASp. & {$[62,74]$} \\
\hline Fyn & Binds and phosphorylates WASp. & {$[60,68,69,73]$} \\
\hline Lyn & Binds and phosphorylates WASp. & [72] \\
\hline $\mathrm{c}-\mathrm{Src}$ & Binding to WASp demonstrated. & {$[69,80,211]$} \\
\hline c-Fgr & Binding to WASp demonstrated. & {$[69,73,80]$} \\
\hline Tec & Binding to WASp demonstrated. & {$[70,212]$} \\
\hline Itk & Binding to WASp demonstrated. & {$[70,212]$} \\
\hline \multicolumn{3}{|c|}{ Sh2-SH3 adaptor molecules } \\
\hline Nck & Binding and recruiting WASp to signalling complexes. & {$[73,75]$} \\
\hline Grb2 & Binding and recruiting WASp to signalling complexes. & {$[32,69-71,75]$} \\
\hline $\mathrm{p} 85 \alpha$ & Direct and indirect binding to WASp, recruitment to signalling complexes. & {$[69,80,81]$} \\
\hline CrkL & Binding to WASp demonstrated. & [79] \\
\hline \multicolumn{3}{|c|}{ Actin binding molecules } \\
\hline profilin & Binds WASp and enhances Arp2/3-mediated actin polymerization. & {$[86]$} \\
\hline cortactin & Binds WASp and enhances Arp2/3-mediated actin polymerization. & [213] \\
\hline VASP & Binds WASp and enhances Arp2/3-mediated actin polymerization. & {$[65]$} \\
\hline \multicolumn{3}{|l|}{ Other } \\
\hline $\mathrm{PLC} \gamma$ & Binding to WASp demonstrated. & {$[69-71,75,80]$} \\
\hline PSTPIP & Binds WASp and allows dephosphorylation by recruiting phosphatase. & {$[60,79,82-84,211]$} \\
\hline SNX9 & Binding and recruiting WASp to signalling complexes. & {$[81]$} \\
\hline
\end{tabular}

motifs for SH3 domain containing proteins (PXXP). Deletion of the polyproline domain abolishes the ability of WASp and N-WASp to induce actin polymerization $[45,65,66]$. Many molecules can bind WASp via their SH3 domains including non-receptor tyrosine kinases, actin binding molecules and adaptor molecules (see Table 1). Members of the Src and Tec family of kinase families can bind to the polyproline domain of WASp through their SH3 domains (see Table 1). Of these, Btk, Hck, Fyn and Lyn can all bind and phosphorylate WASp [60,62,67-74]. Many other kinases have the ability to bind WASp, but further investigations are required to elucidate their function and in vivo relevance (see Table 1). Whilst many kinases also contain $\mathrm{SH} 2$ domain binding motifs, no interaction with WASp through binding of $\mathrm{SH} 2$ domains with phosphorylated tyrosine residues have been reported. Phosphorylation of Y291 of WASp creates a potential SH2 binding motif, although this differs from the Src family SH2 consensus sequence (pYDFI instead of pYEEI).

A second important group of binding partners for WASp are adaptor molecules that contain SH3 domains (Table 1). Nck and Grb2 are SH2-SH3 adaptor molecules, which were among the first identified to bind to WASp. They bind to the polyproline domain of WASp via their SH3 domains $[73,75]$ and can re- cruit other molecules through their SH2 domains. An example of this is the recruitment of WASp via Grb2 binding to the epidermal growth factor receptor after its stimulation [75]. Binding of Nck and Grb2 contributes to N-WASp activation and release of its autoinhibited conformation [76-78] and may function similarly for WASp. Two other SH2-SH3 adaptor molecules that can bind WASp are CrkL and the regulatory subunit $\mathrm{p} 85 \alpha$ of PI-3K. In platelets, CrkL binds WASp via its SH3 domain and recruits the kinase Syk to the complex, which has the potential to tyrosine phosphorylate WASp [79]. Direct binding of $\mathrm{p} 85 \alpha$ to WASp was shown in the lymphoblastoid Namalwa cell line and in monocytic U937 cells $[69,80]$. In T lymphocytes, p85 $\alpha$ binds CD28 and sorting nexin 9 (SNX9), with the latter binding WASp via its SH3 domain [81]. WASp function in platelets and the RAW macrophage cell line appears dependent on PI-3K activity, as inhibition of PI-3K by wortmannin or LY294002 inhibits WASp phosphorylation [32]. Further investigations are needed to define the role of $\mathrm{p} 85 \alpha$ in WASp activation and to determine whether its involvement could be cell type dependent.

Other SH3 domain containing molecules can bind the polyproline domain of WASp. Phospholipase Cgamma (PLC $\gamma)$ is one such molecule, but its role in WASp function has not been studied in detail [69-71, 
75,80]. PLC $\gamma$ also contains two SH2 domains, which could facilitate recruitment or localization of WASp to molecular complexes. The adaptor molecule PSTPIP (proline, serine, threonine-rich phosphatase interacting protein) acts as a scaffold to bind both WASp via its $\mathrm{SH} 3$ domain and the protein-tyrosine phosphatase PTP-PEST via its carboxyl-terminal domain [82,83]. This interaction enables PTP-PEST to dephosphorylate WASp and is important downstream of T cell receptor signalling and immunological synapse formation $[60,82,84]$. Binding of WASp through multiple SH3 domains of adaptor molecules induces dimerisation of WASp to further enhance its activity [85], which provides an additional way to regulate WASp activity.

A third group of molecules that bind WASp also binds actin monomers and enhances WASp-mediated actin polymerization. These include profilin, cortactin and VASP. The dual binding of profilin to monomeric actin and the polyproline domain of WASp enables profilin to recruit monomeric actin to the VCA domain. This step allows utilisation by the activated Arp2/3 complex and subsequent incorporation into nucleated actin filaments [86]. Cortactin contains an SH3 domain through which it can bind to WASp [19]. VASP can not only bind to WASP via its amino-terminal EVH1 domain, but also bind both monomeric actin and filamentous actin via its carboxyl-terminal EVH2 domain [65].

\section{VCA domain}

The carboxyl terminal VCA domain of WASp defines the business end of the protein and is characteristic of all the proteins in the WASp family. In WASp it contains three regions: the verprolin homology domain, central domain (which was originally thought to be a cofilin homology domain) and the terminal acidic domain. The VCA domain of cytosolic WASp is bound to the GBD, restricting recruitment of Arp2/3 and subsequent actin polymerization $[52,53]$. The Arp $2 / 3$ complex is a stable complex of seven different proteins that mediates reorganisation of actin monomers into filaments. Arp2 and 3 are structurally homologous to actin molecules while the other five proteins, called actin related protein complex component (ARPC) 1-5, have unique structures. Two models have been proposed to explain the mechanism of Arp2/3-mediated actin filament branching. In the dendritic nucleation model, Arp2/3 is bound to the mother filament and the daughter filament is formed by the Arp2, Arp3 and WASp-bound actin monomer. In this model nucle- ation is initiated from the side of the pre-existing filament [87-89]. The barbed-end branching model proposes that Arp2/3 binds to the barbed end of an existing filament and incorporates one actin monomer (delivered by WASp) or either of the actin homologous Arp2 or Arp3 subunits onto the filament. The daughter filament then is formed by the remaining two units (WASp-delivered actin monomer or actin homologous units Arp2 or Arp3), and elongation of both daughter and mother filament occurs synchronously [90,91]. An activated ARP2/3 complex in the presence of monomeric actin, ATP and the VCA domain of any of the WASp family members are the minimal requirements for actin polymerization $[38,92,93]$.

Upon release of the autoinhibited conformation of WASp, the CA region of the VCA domain is able to bind Arp2/3 via a conserved stretch of approximately 15 amino acids (465-483 in WASp). These form an amphipathic helix that exposes long-chain hydrophobic residues and a single positively charged arginine residue (aa 477) on one face of the helix, to which Arp2/3 is predicted to bind [94]. Constitutive phosphorylation by casein kinase 2 of two serine residues within the WASp VCA domain (S483 and S484) further enhances Arp2/3 binding [95]. Actin monomers are recruited by binding to amino acid residues within the $\mathrm{V}$ and $\mathrm{C}$ domains, which assists in delivering actin monomers to the activated Arp2/3 complex [96-98]. Binding of actin-binding molecules, such as profilin, to the polyproline domain likely also assists in the delivery of actin monomers to the $\mathrm{V}$ and $\mathrm{C}$ domain of WASp [86].

\section{Cellular function}

Activation of WASp occurs at multiple levels either through activation by $\mathrm{Cdc} 42$ or by phosphorylation of Y291. The large number of binding partners that interact with different domains of WASp provides additional ways to regulate function. In addition, WASp binding partners can be involved in dimerisation of WASp molecules, further enhancing WASp activity. Thus, WASp emerges as an important platform for regulating actin polymerization through activation of the Arp2/3 complex, which is key for cytoskeletal reorganisation. It is therefore not surprising that lack of WASp results in a wide range of defects of cellular function involving all haematopoietic cell lineages (see Fig. 2). 


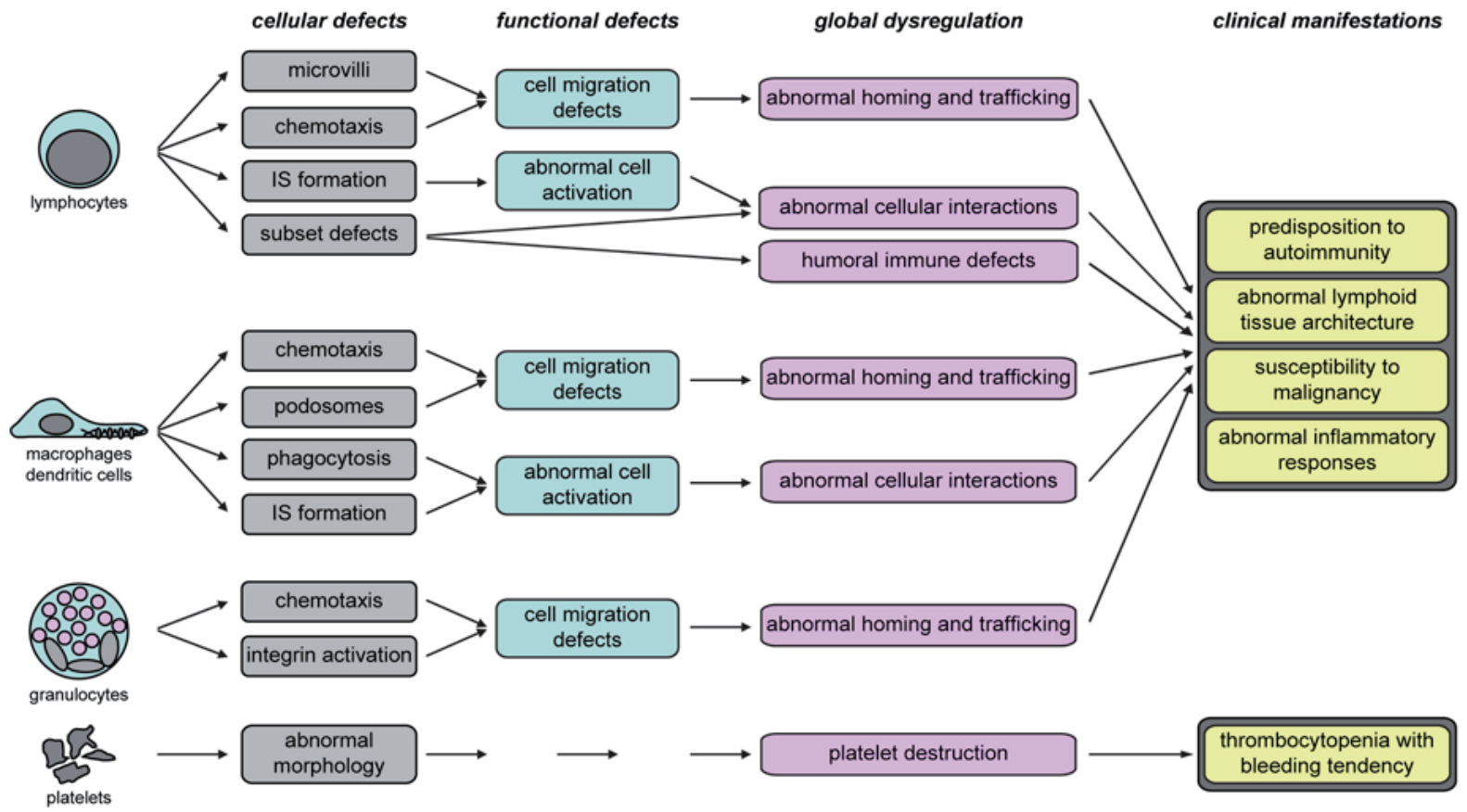

Fig. 2. Lack of WASp causes defective function of multiple haematopoietic cell lineages. WASp is required for many functions in haematopoietic cells and its absence results in defects of cellular function. The combination of defective function of multiple immune cell lineages culminates in global dysregulation of immune function, which manifests as abnormal inflammatory responses, autoimmunity and susceptibility to malignancy. In addition, lack of WASp causes a specific platelet defect, which results in increased platelet destruction and bleeding tendency.

\section{WASp in the Haematopoietic system}

Unlike the ubiquitously expressed N-WASp, WASp expression is restricted to the haematopoietic lineage of cells and is detected even in the earliest cells of the developing immune system in the aorto-gonadmesonephros (AGM) region [99]. Despite the presence of WASp in cells of the early developing immune system, certain functions mediated by N-WASp or WAVE proteins may show some redundancy. In contrast, N-WASp and WAVE 2 KO mice are embryonic lethal $[100,101]$ and WAVE 1 KO mice exhibit severe neuronal abnormalities [102]. The early expression and necessity for WASp was demonstrated by the apparent non-random inactivation of the $\mathrm{X}$ chromosome in the haematopoietic system of heterozygote females [103]. Where $\mathrm{X}$ inactivation has been skewed against the normal WAS allele, there have been cases of females with a WAS/XLT phenotype [104,105]. The requirement for WASp in the developing immune system is not fully understood. Wild type haematopoietic cells have a selective advantage in homing to the bone marrow as compared to WASp knock out (WAS KO) cells [106]. However once in this niche, there does not seem to be a critical role for WASp, although activating muta- tions lead to severe neutropenia [107]. Haematopoietic progenitor levels and development of B cells in the bone marrow in particular both appear to be normal. This is in direct contrast to more mature cells of the lymphoid compartment, in which WASp confers a selective advantage $[108,109]$. In fact, as lymphocytes and myeloid lineage cells mature they seem to have a greater requirement for WASp in order to function. Several WAS patients have been described where secondary de novo mutations have resulted in a reversion to wild-type protein, leading to somatic mosaicism and suggesting a selective advantage for WASp positive cells [110-112]. In fact WAS seems to have a high prevalence of mosaicism even compared to other immunodeficiencies $[113,114]$. The selective advantage for wild-type protein expression is restricted to the lymphoid lineage, particularly in T cell and NK cell cells. Selective advantage depends upon where the reversion occurs, with some mutations showing only a $\mathrm{T}$ cell advantage $[115,116]$, whereas other mutations confer advantage to both NK and T cell lineages [117119]. In most cases $T$ cell reversion is not sufficient to abrogate disease [116] even though $\mathrm{T}$ cells are one of the most affected lineages. This is probably because 
only a limited repertoire is corrected, but also as a result of the multilineage nature of the disease. So far little selective advantage has been observed for B cells in mosaic patients [115].

\section{0. $T$ cell defects}

Although human T cell development appears normal in WAS patients, the circulating lymphocyte number is reduced [120] and progressively declines throughout childhood [121,122]. T cells may exhibit morphological defects with reduced microvilli on the cell surface [123], which could affect normal migratory function, or reflect the activation state of the cell [124]. One of the major defects of WASp null T cells is their inability to proliferate in response to various stimuli [120]. They do not form an optimal immunological synapse (IS) $[84,125]$, leading to defective receptor capping and subsequent IL-2 secretion upon CD $3 \varepsilon$ cross linking. However, in some circumstances an IS can be formed [126]. It has also been proposed that it is not the initial IS formation but the re-formation of the synapse that is defective [127]. The mechanism leading to a poorly formed IS probably results from inefficient actin polymerization [128] or an inability to assemble signalling partners, such as CD2 associated protein, that are normally held in place by a scaffold involving WASp [84]. Upon ligation of the T cell receptor (TCR), WASp is recruited to lipid rafts which allow lateral movement of the TCR. In WAS patients and WAS KO mice, the reduced number and impaired upregulation of the rafts results in inefficient $\mathrm{T}$ cell activation in response to stimuli [125]. Although WASp mainly functions in actin polymerization, a WASp mutant with the VCA domain deleted, which is unable to polymerise actin, remains capable of enhancing NFAT translocation and transcriptional activation [129]. There is a proposed role for N-WASp and WASp in T cell development as dual WASp/N-WASp KO mice exhibit severe thymic hypocellularity [130]. Mice deficient in Vav-1, a guanine exchange factor (GEF) for Rho type GTPases that is implicated in actin cytoskeleton remodelling, have a similar blockage in thymic development at the DN3 stage [131]. Coronin-1 KO mice, which have increased actin polymerization, have $\mathrm{T}$ cell defects in the spleen and lymph nodes [132]. DOCK8 is reported to be a Rho-Rac GEF for $\mathrm{Cdc} 42$, and deficiency in DOCK8 would therefore be predicted to result in some phenotypic features in common with WAS. In fact, striking clinical and immunological similarities have been observed, both in humans and in a recently reported mouse model of DOCK8 deficiency [133, 134]. The greater severity of DOCK 8 deficiency as compared to WASp deficiency alone, may reflect GEF activity of DOCK8 that is not restricted to $\mathrm{Cdc} 42$, or Cdc42-mediated functions that do not involve WASp activity. Additionally, DOCK8 deficiency may compromise both N-WASp and WASp functions.

In addition to defects in CD4+ and CD8+ T cells, functional abnormalities in the regulatory $\mathrm{T}$ cell (Treg) populations are seen in both WASp deficient humans and mice [135-137]. Tregs are important in $\mathrm{T}$ cell homeostasis and control auto-reactive T cells. Treg abnormalities could partially explain the propensity for autoimmune dysregulation in WAS patients. The reexpression of WASp following a reversion mutation in a patient, demonstrated a selective advantage in the Treg population with a corresponding decrease in autoimmune disease and improved clinical condition [136].

\section{1. $B$ cell defects}

Until recently it was thought that B cells were less severely affected by a lack of WASp compared to other lineages. Animal models initially revealed few defects in the B cell compartment, which were attributed in part to lack of T cell help $[138,139]$. WAS patients have increased prevalence of B cell malignancy [140], impaired antibody responses particularly to polysaccharide antigens $[121,140]$, reduced $B$ cell numbers and smaller germinal centres. B cells from WAS patients have defective transmembrane signalling [141] and reduced numbers of microvilli on their cell surface [138]. EBV transformed cell lines have defective actin polymerization [142]. B cells have defective polarisation, spreading, aggregation and migration in response to CXCL13 [143,144], and are defective in producing filopodia in response to bradykinin [145]. Specific subsets of B cells are also abnormal. Marginal Zone B cells (MZB) are reduced in WAS patients [146] and in WAS KO mice [144,147], consistent with a defect in response to polysaccharide antigens. Furthermore they fail to migrate in response to sphingosine-1-phosphate, which is crucial for MZB homing. Transplantation experiments further revealed a role for WASp in peripheral homeostasis. Although a lack of WASp does not affect development, WASp expression increases as B cells mature in the periphery. At this stage, there is a selective advantage of wild type over WAS null B cells. Similar results were observed in a revertant 
patient where the mature B cell population expressed more WASp than immature B cells [108]. The defects in B cells are not as well defined compared to other lineages, but are consistent with abnormal regulation of the actin cytoskeleton and may be particularly important for development of autoimmunity.

\section{NK Cell defects}

NK cells are an important part of the innate immune system that removes virally infected cells, parasites and malignant cells [148]. They are predominantly found in the blood, but upon instigation of an inflammatory response rapidly migrate to the site of inflammation where they kill target cells and release cytokines to further stimulate the immune response [149]. As has been shown for T cells, NK cell cytotoxicity requires formation of an immunological synapse and lipid raft clustering, which in itself relies upon actin polymerization. Both WASp and actin are present in the IS [150]. WAS patient NK cells, although increased in number [151], have impaired cytotoxicity, which can be corrected by the addition of IL-2 [152]. This reversibility suggests that a lack of signal transduction is responsible for the defect. It is this lack of responsiveness to viruses (particularly those with oncogenic potential) that probably accounts for the increased incidence of malignancy in WAS. Furthermore, WASp is involved in the transcriptional regulation of cytokines via the translocation of NFAT into the nucleus and activation of transcriptional factors [153]. As in T cells, these events occur independently of WASp's actin polymerization function. More recently, migration of NK cells through ICAM1 and VCAM-1 has been shown to rely upon WASp. WASp is rapidly phosphorylated following chemokine stimulation, and WAS KO NK cells have reduced ability to upregulate CD18 expression in response to CXCL12 [154]. The importance of WASp in NK cells is demonstrated by the selective advantage conferred by spontaneous revertant mutations in WAS patients [119].

\section{Invariant NKT cells}

Invariant NKT cells are T cells that have both NK cell receptors and $\mathrm{T}$ cell receptors, but which recognize lipid antigens instead of peptide antigens via the non-classical class I MHC molecule CD1d [155]. By releasing a wide range of cytokines upon TCR engagement, they are thought to be particularly important in initial responses to infection, as well as in protection from autoimmunity and clearance of malignant cells. iNKT cells in SAP KO mice are completely absent, suggesting a role in preventing EBV specific malignancies observed with SAP deficiency. Interestingly these same malignancies are often seen in WAS. In both WAS patients and KO murine models, iNKT cells are severely reduced [156,157] and secrete less cytokine when stimulated. This may contribute to the increased malignancy observed in WAS patients.

\section{Myeloid defects}

Many defects of the immune system in WAS have been discovered in cells of the myeloid lineage. The ability of neutrophils, DC and monocytes to respond appropriately to a stimulus, whether through migration, efficient antigen presentation or through phagocytosis, relies upon quick and regulated de novo actin polymerization.

Once stimulated, macrophages and DC have to migrate through tissues. They home either to sites of inflammation, or to secondary lymphoid tissues to initiate effector functions of other cells of the immune system. Cell locomotion is controlled by protrusions of the cell membrane and relies upon spatial and temporal regulation of actin polymerization. WAS macrophages have abrogated chemotactic responses to fMLP, MCP1 [158], and CSF-1 [159], as compared to normal cells. DC from WAS patients also have intrinsic defects in their actin regulation. When stimulated in vitro with fMLP or RANTES, WAS DCs are non-motile. In addition, they do not polarise or extend dendritic processes [160]. Furthermore, Langerhans cell and DC migration are impaired in vivo [147,161]. Neutrophils do not assemble integrins properly either further suggesting migratory defects [162]. The defective migration coupled to impaired $T$ cell activation probably contributes to a large proportion of the pathology observed in WAS $[161,163]$.

Podosomes are thought to participate in cell motility through adhesion to extracellular matrix proteins and localized release of proteases. The latter allows the cells to migrate through the substratum; additionally release of MMPs occurs in osteoclasts [164] and vascular smooth muscle cells [165]. Podosomes are highly dynamic actin based structures that have a half-life of 2-12 minutes and are in close contact with the substratum. Podosomes have a basic actin core with actin regulatory proteins surrounded by a ring of vinculin and 
other cellular adhesion molecules [166]. Podosome assembly and disassembly in both macrophages and DC is tightly regulated by WASp, WIP and Cdc42. Knock down of WASp using RNAi leads to reduced podosome numbers [167], and overexpression of the dominant negative form of $\mathrm{Cdc} 42$ (V12Cdc42) leads to podosome disassembly [168,169]. Macrophages [168] DCs [169] and osteoclasts [170] from WAS patients lack podosomes. In fact, similar to NK cells [154] WAS DC do not adhere as strongly to ICAM-1 and do not assemble integrins around podosomes [171]. Milder phenotype XLT patients have reduced podosome numbers, but correlation between podosome number and severity of clinical phenotype has not yet been established. WASp is recruited to podosomes as part of a complex of molecules including FBP17, WIP and dynamin2 [172]. WASp and WIP both associate in the podosome, and a lack of either results in loss of podosomes [22,33,173]. More recently, phosphorylation of WASp is thought to be crucial in the formation and turnover of podosomes [30,174].

Aberrant chemotaxis in macrophages and DC is therefore due to at least two defects. Firstly there is an abrogation in filopodia mediated by Cdc42 and WASp, which is crucial for chemotaxis $[175,176]$. Secondly abnormal polarisation and adherence to substrata leads to an inability to direct movement in a regulated manner. In deletion experiments, the minimal region of WASp required for chemotaxis is the VCA region. This is also the minimal region needed to stimulate actin nucleation, further linking the defects in WAS with dysregulation of actin polymerization [177]. Experiments where WASp is introduced back into WAS KO cells restore podosome formation [170,178-180] and partially restore defective migration [180].

WAS patient macrophages have a defect in $\mathrm{IgG}$ mediated phagocytosis and fail to efficiently assemble a phagocytic cup (normally comprised of F-actin and phosphorylated proteins including WASp [34]) although binding of $\mathrm{IgG}$ coated latex beads to the cell surface is normal [181]. Similarly when phagocytosis of apoptotic cells are investigated, WAS macrophages exhibit a defect in vitro and in vivo [182].

\section{Platelet defects}

Thrombocytopenia and small platelets are classical features of WAS [120] and bleeding is a major cause of morbidity and mortality [140]. However, the exact role of WASp in platelet development and function is still not known. In vitro experiments have shown abnormal cytoarchitecture in WAS megakaryocytes, but the platelets formed in this system were of normal size [183]. As splenectomy can increase platelet numbers, in non-splenectomized patients the low numbers were thought to result from increased destruction. Indeed murine WAS KO platelets are destroyed quicker than wild-type platelets when transferred into wild-type recipients, suggesting an inherent defect. WAS patients are particularly susceptible to autoimmune thrombocytopenia, which is mediated by anti-platelet antibodies and in many patients likely compounds the splenic mediated platelet destruction [184]. Additionally WAS megakaryocytes prematurely form proplatelets, resulting in impaired thrombopoiesis [185], Interestingly, WASp deficient platelets can activate Arp2/3 and make F-actin independent of WASp [90]. Together this evidence suggests that in most patients thrombocytopenia is mediated by a combination of several mechanisms, but further investigations are required to clarify this situation.

\section{Autoimmunity and malignancy}

The intrinsic defects in phagocytosis, chemotaxis, cytotoxicity, apoptosis and cell signalling appear to contribute to more than just the immunodeficiency observed in WAS. The high incidence of autoimmunity, inflammatory conditions and vasculitis seen in patients with WAS and XLT can develop even following bone marrow transplantation [186,187]. Management of these conditions continues to increase in importance as the management of the immunodeficiency and thrombocytopenia improves [140,188]. Abnormal Tregs have been implicated in the onset of autoimmunity by unbalancing T cell homeostasis [135-137]. Murine models are susceptible to colitis [139], which can also be induced upon transfer of WAS Tregs [189]. The peripheral tolerance that follows elimination of autoreactive $\mathrm{T}$ cells relies upon effective cell killing via FASL [190]. Even though FAS induced apoptosis is intact, secretion of active FASL is reduced, contributing to inefficient TCR-induced apoptosis and predisposition to autoimmunity [191]. Dysregulation of B cell tolerance is supported by the presence of autoantibodies in WAS patients and in both WASp null and phosphorylation mutant mice $[30,136,191]$. The ineffective phagocytosis of apoptotic cells could contribute to the aetiology of autoimmunity [182] by causing unchecked inflammatory responses or unbalanced 
exposure to auto-antigens. In $\mathrm{C} 1 \mathrm{q}$ deficient mice this has been linked to systemic lupus erythematosus [192]. Abnormal immune cell migration can lead to abnormal antigen presentation in the periphery instead of in lymphoid organs. This spatial dysregulation of antigen presentation and immune activation could initiate inflammation and cause the severe eczema observed in WAS patients.

Bypassing tolerance checkpoints for B and T cells has been proposed as a mechanism for lymphoid malignancy [193]. Chronic stimulation of autoreactive cells and ineffective clearance of virally infected cells could be a mechanism through which malignant lymphomas arise [194]. Because NK cell cytotoxicity is impaired in WAS patients $[150,152]$, removal of virally infected cells is likely to be also impaired. The role of these cells in the development of malignancy is an area of future work. Recently, activating mutations in WASp (which give rise to XLN) have been found to lead to genetic instability through dysregulation of actin polymerization [107].

\section{Treatment}

The clinical variability, breadth of complications and unpredictable clinical course present a major challenge for the management of Wiskott Aldrich Syndrome. Early diagnosis is essential to reduce the likelihood of complications and subsequent long term morbidity. Management can be then be planned according to clinical presentation, ongoing clinical course, gene mutation and level of WASp protein expression. Antibiotic prophylaxis (including Pneumocystis jirovecii prophylaxis), immunoglobulin replacement therapy, vaccination (live vaccine are not recommended) and platelet transfusions for severe or life threatening haemorrhage may all be required for patients with classical severe WAS. Aggressive treatment of eczema and infections (particularly Herpes viruses) is essential. Severe thrombocytopenia with recurrent haemorrhages is a particular problem. Rituximab (anti-CD20) can be effective when there is an autoimmune component to the thrombocytopenia. In resistant cases splenectomy may be necessary; however subsequent risk of severe sepsis (even following stem cell transplant) is significantly increased. Haematopoietic stem cell transplant, which corrects defects in all haematopoietic compartments, is the definitive treatment of choice [195-197]. Survival rates of over $85 \%$ following transplant are now obtained even with unrelated donors, but the proceedure is less successful with haploidentical donors [198-200]. Mixed chimerism may be associated with persistent autoimmunity [187]. One alternative treatment is somatic gene therapy. Initial experiments introducing WASp into null cells restored cytoskeletal abnormalities [169, 170,178,201] and cell signalling [202-204]. Moreover, transduction of murine haematopoietic stem cells with retroviral and lentiviral vectors, followed by engraftment of murine models, corrected multiple abnormalities of the immune system [179,180,205-207]. Further refinement has led to the use of endogenous human promoter sequences to express WASp at physiological levels [208-210]. Clinical trials using gammaretroviral vectors and lentiviral vectors are underway and show promise (Boztug et al, in press).

\section{Concluding remarks}

WASp function is regulated at several levels including release and stabilisation of an autoinhibitory conformation, oligomerisation and proteasomal degradation. Activated WASp provides an important scaffold for signalling molecules. As an adaptor molecule, WASp may be crucial for subcellular organization of signalling complexes to the actin cytoskeleton. While there might be a certain level of redundancy, WASp emerges as a significant regulator of the haematopoietic cytoskeletal system and is crucial for normal immune cell function. While insights into WASp activities have been instructive in our understanding of the actin cytoskeleton, they have also paved the way towards development of more effective therapies.

\section{Acknowledgements}

This work was supported by the Wellcome Trust.

\section{References}

[1] M.H. Albert, T.C. Bittner, S. Nonoyama, L.D. Notarangelo, S. Burns, K. Imai, T. Espanol, A. Fasth, I. Pellier, G. Strauss, T. Morio, B. Gathmann, J.G. Noordzij, C. Fillat, M. Hoenig, M. Nathrath, A. Meindl, P. Pagel, U. Wintergerst, A. Fischer, A.J. Thrasher, B.H. Belohradsky and H.D. Ochs, X-linked thrombocytopenia (XLT) due to WAS mutations: clinical characteristics, long-term outcome, and treatment options, Blood 115 (2010), 3231-3238

[2] Q. Zhu, M. Zhang, R.M. Blaese, J.M. Derry, A. Junker, U. Francke, S.H. Chen and H.D. Ochs, The Wiskott-Aldrich syndrome and $\mathrm{X}$-linked congenital thrombocytopenia are caused by mutations of the same gene, Blood 86 (1995), 3797-3804. 
[3] K. Imai, T. Morio, Y. Zhu, Y. Jin, S. Itoh, M. Kajiwara, J. Yata, S. Mizutani, H.D. Ochs and S. Nonoyama, Clinical course of patients with WASP gene mutations, Blood $\mathbf{1 0 3}$ (2004), 456-464.

[4] K. Devriendt, A.S. Kim, G. Mathijs, S.G. Frints, M. Schwartz, J.J. Van Den Oord, G.E. Verhoef, M.A. Boogaerts, J.P. Fryns, D. You, M.K. Rosen and P. Vandenberghe, Constitutively activating mutation in WASP causes X-linked severe congenital neutropenia, Nat Genet 27 (2001), 313-317.

[5] P.J. Ancliff, M.P. Blundell, G.O. Cory, Y. Calle, A. Worth, H. Kempski, S. Burns, G.E. Jones, J. Sinclair, C. Kinnon, I.M. Hann, R.E. Gale, D.C. Linch and A.J. Thrasher, Two novel activating mutations in the Wiskott-Aldrich syndrome protein result in congenital neutropenia, Blood 108 (2006), 2182-2189.

[6] K. Beel, M.M. Cotter, J. Blatny, J. Bond, G. Lucas, F. Green, V. Vanduppen, D.W. Leung, S. Rooney, O.P. Smith, M.K. Rosen and P. Vandenberghe, A large kindred with X-linked neutropenia with an I294T mutation of the Wiskott-Aldrich syndrome gene, Br J Haematol 144 (2009), 120-126.

[7] K.G. Campellone, N.J. Webb, E.A. Znameroski and M.D. Welch, WHAMM is an Arp2/3 complex activator that binds microtubules and functions in ER to Golgi transport, Cell 134 (2008), 148-161.

[8] S. Kurisu and T. Takenawa, The WASP and WAVE family proteins, Genome Biol 10 (2009), 226.

[9] E.V. Linardopoulou, S.S. Parghi, C. Friedman, G.E. Osborn, S.M. Parkhurst and B.J. Trask, Human subtelomeric WASH genes encode a new subclass of the WASP family, PLoS Genet 3 (2007), e237

[10] J.M. Derry, H.D. Ochs and U. Francke, Isolation of a novel gene mutated in Wiskott-Aldrich syndrome, Cell 78 (1994), 635-644.

[11] H. Miki, K. Miura and T. Takenawa, N-WASP, a novel actindepolymerizing protein, regulates the cortical cytoskeletal rearrangement in a PIP2-dependent manner downstream of tyrosine kinases, EMBO J 15 (1996), 5326-5335.

[12] P. Aspenstrom, U. Lindberg and A. Hall, Two GTPases, $\mathrm{Cdc} 42$ and Rac, bind directly to a protein implicated in the immunodeficiency disorder Wiskott-Aldrich syndrome, Curr Biol 6 (1996), 70-75.

[13] N. Ramesh, I.M. Anton, J.H. Hartwig and R.S. Geha, WIP, a protein associated with wiskott-aldrich syndrome protein, induces actin polymerization and redistribution in lymphoid cells, Proc Natl Acad Sci USA 94 (1997), 14671-14676.

[14] H.Y. Ho, R. Rohatgi, L. Ma and M.W. Kirschner, CR16 forms a complex with N-WASP in brain and is a novel member of a conserved proline-rich actin-binding protein family, Proc Natl Acad Sci U S A 98 (2001), 11306-11311.

[15] M. Kato, H. Miki, S. Kurita, T. Endo, H. Nakagawa, S. Miyamoto and T. Takenawa, WICH, a novel verprolin homology domain-containing protein that functions cooperatively with N-WASP in actin-microspike formation, Biochem Biophys Res Commun 291 (2002), 41-47.

[16] I.M. Anton, W. Lu, B.J. Mayer, N. Ramesh and R.S. Geha, The Wiskott-Aldrich syndrome protein-interacting protein (WIP) binds to the adaptor protein Nck, J Biol Chem 273 (1998), 20992-20995.

[17] B.F. Volkman, K.E. Prehoda, J.A. Scott, F.C. Peterson and W.A. Lim, Structure of the N-WASP EVH1 domain-WIP complex: insight into the molecular basis of Wiskott-Aldrich Syndrome, Cell 111 (2002), 565-576.

[18] F.C. Peterson, Q. Deng, M. Zettl, K.E. Prehoda, W.A. Lim, M. Way and B.F. Volkman, Multiple WASP-interacting pro- tein recognition motifs are required for a functional interaction with N-WASP, J Biol Chem 282 (2007), 8446-8453.

[19] N. Martinez-Quiles, R. Rohatgi, I.M. Anton, M. Medina, S.P. Saville, H. Miki, H. Yamaguchi, T. Takenawa, J.H. Hartwig, R.S. Geha and N. Ramesh, WIP regulates N-WASP-mediated actin polymerization and filopodium formation, $\mathrm{Nat}$ Cell Biol 3 (2001), 484-491.

[20] R.P. Lim, A. Misra, Z. Wu and T. Thanabalu, Analysis of conformational changes in WASP using a split YFP, Biochem Biophys Res Commun 362 (2007), 1085-1089.

[21] H.Y. Ho, R. Rohatgi, A.M. Lebensohn, M. Le, J. Li, S.P. Gygi and M.W. Kirschner, Toca-1 mediates Cdc42-dependent actin nucleation by activating the N-WASP-WIP complex, Cell 118 (2004), 203-216.

[22] H.C. Chou, I.M. Anton, M.R. Holt, C. Curcio, S. Lanzardo, A. Worth, S. Burns, A.J. Thrasher, G.E. Jones and Y. Calle, WIP regulates the stability and localization of WASP to podosomes in migrating dendritic cells, Curr Biol 16 (2006), 2337-2344.

[23] M.A. de la Fuente, Y. Sasahara, M. Calamito, I.M. Anton, A. Elkhal, M.D. Gallego, K. Suresh, K. Siminovitch, H.D. Ochs, K.C. Anderson, F.S. Rosen, R.S. Geha and N. Ramesh, WIP is a chaperone for Wiskott-Aldrich syndrome protein (WASP), Proc Natl Acad Sci U S A 104 (2007), 926-931.

[24] A. Konno, M. Kirby, S.A. Anderson, P.L. Schwartzberg and F. Candotti, The expression of Wiskott-Aldrich syndrome protein (WASP) is dependent on WASP-interacting protein (WIP), Int Immunol 19 (2007), 185-192.

[25] J.N. Luthi, M.J. Gandhi and J.G. Drachman, X-linked thrombocytopenia caused by a mutation in the Wiskott-Aldrich syndrome (WAS) gene that disrupts interaction with the WAS protein (WASP)-interacting protein (WIP), Exp Hematol 31 (2003), 150-158.

[26] D.M. Stewart, L. Tian and D.L. Nelson, Mutations that cause the Wiskott-Aldrich syndrome impair the interaction of Wiskott-Aldrich syndrome protein (WASP) with WASP interacting protein, J Immunol 162 (1999), 5019-5024.

[27] M.I. Lutskiy, F.S. Rosen and E. Remold-O'Donnell, Genotype-proteotype linkage in the Wiskott-Aldrich syndrome, J Immunol 175 (2005), 1329-1336.

[28] Y. Jin, C. Mazza, J.R. Christie, S. Giliani, M. Fiorini, P. Mella, F. Gandellini, D.M. Stewart, Q. Zhu, D.L. Nelson, L.D. Notarangelo and H.D. Ochs, Mutations of the Wiskott-Aldrich Syndrome Protein (WASP): hotspots, effect on transcription, and translation and phenotype/genotype correlation, Blood 104 (2004), 4010-4019.

[29] S. Suetsugu, M. Hattori, H. Miki, T. Tezuka, T. Yamamoto, K. Mikoshiba and T. Takenawa, Sustained activation of NWASP through phosphorylation is essential for neurite extension, Dev Cell 3 (2002), 645-658.

[30] M.P. Blundell, G. Bouma, J. Metelo, A. Worth, Y. Calle, L.A. Cowell, L.S. Westerberg, D.A. Moulding, S. Mirando, C. Kinnon, G.O. Cory, G.E. Jones, S.B. Snapper, S.O. Burns and A.J. Thrasher, Phosphorylation of WASp is a key regulator of activity and stability in vivo, Proc Natl Acad Sci U S A 106 (2009), 15738-15743.

[31] A. Shcherbina, H. Miki, D.M. Kenney, F.S. Rosen, T. Takenawa and E. Remold-O'Donnell, WASP and N-WASP in human platelets differ in sensitivity to protease calpain, Blood 98 (2001), 2988-2991.

[32] A. Oda, H.D. Ochs, B.J. Druker, K. Ozaki, C. Watanabe, M. Handa, Y. Miyakawa and Y. Ikeda, Collagen induces tyrosine phosphorylation of Wiskott-Aldrich syndrome protein in human platelets, Blood 92 (1998), 1852-1858. 
[33] S. Tsuboi, Requirement for a complex of Wiskott-Aldrich syndrome protein (WASP) with WASP interacting protein in podosome formation in macrophages, J Immunol 178 (2007), 2987-2995

[34] S. Tsuboi and J. Meerloo, Wiskott-Aldrich syndrome protein is a key regulator of the phagocytic cup formation in macrophages, J Biol Chem 282 (2007), 34194-34203.

[35] Y. Sasahara, R. Rachid, M.J. Byrne, M.A. de la Fuente, R.T. Abraham, N. Ramesh and R.S. Geha, Mechanism of recruitment of WASP to the immunological synapse and of its activation following TCR ligation, Mol Cell 10 (2002), 1269-1281.

[36] D.N. Savoy, D.D. Billadeau and P.J. Leibson, Cutting edge: WIP, a binding partner for Wiskott-Aldrich syndrome protein, cooperates with Vav in the regulation of T cell activation, J Immunol 164 (2000), 2866-2870.

[37] V. Moreau, F. Frischknecht, I. Reckmann, R. Vincentelli, G. Rabut, D. Stewart and M. Way, A complex of N-WASP and WIP integrates signalling cascades that lead to actin polymerization, Nat Cell Biol 2 (2000), 441-448.

[38] K.E. Prehoda, J.A. Scott, M.R. Dyche and W.A. Lim, Integration of multiple signals through cooperative regulation of the N- WASP-Arp2/3 complex, Science 290 (2000), 801-806.

[39] R. Rohatgi, H.Y. Ho and M.W. Kirschner, Mechanism of NWASP activation by CDC42 and phosphatidylinositol 4, 5bisphosphate, J Cell Biol 150 (2000), 1299-1310.

[40] H.N. Higgs and T.D. Pollard, Activation by Cdc42 and PIP(2) of Wiskott-Aldrich syndrome protein (WASp) stimulates actin nucleation by Arp2/3 complex, J Cell Biol 150 (2000), 1311-1320

[41] K. Imai, S. Nonoyama, H. Miki, T. Morio, K. Fukami, Q. Zhu, A. Aruffo, H.D. Ochs, J. Yata and T. Takenawa, The pleckstrin homology domain of the Wiskott-Aldrich syndrome protein is involved in the organization of actin cytoskeleton, Clin Immunol 92 (1999), 128-137.

[42] R. Insall and L. Machesky, PH domains in WASP - a bug in the system? Wiskott-Aldrich syndrome protein, Trends Cell Biol 9 (1999), 211-212.

[43] H. Miki, S. Suetsugu and T. Takenawa, WAVE, a novel WASP-family protein involved in actin reorganization induced by Rac, EMBO J 17 (1998), 6932-6941.

[44] S.B. Rong and M. Vihinen, Structural basis of WiskottAldrich syndrome causing mutations in the WH1 domain, $J$ Mol Med 78 (2000), 530-537.

[45] S. Suetsugu, H. Miki, H. Yamaguchi and T. Takenawa, Requirement of the basic region of N-WASP/WAVE2 for actinbased motility, Biochem Biophys Res Commun 282 (2001), 739-744.

[46] L. Hemsath, R. Dvorsky, D. Fiegen, M.F. Carlier and M.R. Ahmadian, An electrostatic steering mechanism of $\mathrm{Cdc} 42$ recognition by Wiskott-Aldrich syndrome proteins, Mol Cell 20 (2005), 313-324.

[47] R. Kolluri, K.F. Tolias, C.L. Carpenter, F.S. Rosen and T. Kirchhausen, Direct interaction of the Wiskott-Aldrich syndrome protein with the GTPase Cdc42, Proc Natl Acad Sci U S A 93 (1996), 5615-5618.

[48] M.G. Rudolph, P. Bayer, A. Abo, J. Kuhlmann, I.R. Vetter and $\mathrm{A}$. Wittinghofer, The $\mathrm{Cdc} 42 / \mathrm{Rac}$ interactive binding region motif of the Wiskott Aldrich syndrome protein (WASP) is necessary but not sufficient for tight binding to $\mathrm{Cdc} 42$ and structure formation, Journal of Biological Chemistry 273 (1998), 18067-18076.

[49] M. Symons, J.M. Derry, B. Karlak, S. Jiang, V. Lemahieu, F. McCormick, U. Francke and A. Abo, Wiskott-Aldrich syndrome protein, a novel effector for the GTPase CDC42Hs, is implicated in actin polymerization, Cell 84 (1996), 723734.

[50] N. Abdul-Manan, B. Aghazadeh, G.A. Liu, A. Majumdar, O. Ouerfelli, K.A. Siminovitch and M.K. Rosen, Structure of Cdc42 in complex with the GTPase-binding domain of the 'Wiskott-Aldrich syndrome' protein, Nature 399 (1999), 379-383.

[51] P.D. Burbelo, D. Drechsel and A. Hall, A conserved binding motif defines numerous candidate target proteins for both Cdc42 and Rac GTPases, J Biol Chem 270 (1995), 2907129074.

[52] M. Buck, W. Xu and M.K. Rosen, Global disruption of the WASP autoinhibited structure on $\mathrm{Cdc} 42$ binding. Ligand displacement as a novel method for monitoring amide hydrogen exchange, Biochemistry 40 (2001), 14115-14122.

[53] A.S. Kim, L.T. Kakalis, N. Abdul-Manan, G.A. Liu and M.K. Rosen, Autoinhibition and activation mechanisms of the Wiskott-Aldrich syndrome protein, Nature 404 (2000), 151-158.

[54] M. Lorenz, H. Yamaguchi, Y. Wang, R.H. Singer and J. Condeelis, Imaging sites of $\mathrm{N}$-wasp activity in lamellipodia and invadopodia of carcinoma cells, Curr Biol 14 (2004), 697-703.

[55] P. Sukumvanich, V. DesMarais, C.V. Sarmiento, Y. Wang, I. Ichetovkin, G. Mouneimne, S. Almo and J. Condeelis, Cellular localization of activated N-WASP using a conformationsensitive antibody, Cell Motil Cytoskeleton 59 (2004), 141152.

[56] M. Cammer, J.C. Gevrey, M. Lorenz, A. Dovas, J. Condeelis and D. Cox, The mechanism of CSF-1-induced WiskottAldrich syndrome protein activation in vivo: a role for phosphatidylinositol 3-kinase and Cdc42, J Biol Chem 284 (2009), 23302-23311.

[57] E. Torres and M.K. Rosen, Protein tyrosine kinase and GTPase signals cooperate to phosphorylate and activate WASP/N-WASP, J Biol Chem 281 (2006), 3513-3520.

[58] H. Park and D. Cox, Cdc42 regulates Fc gamma receptormediated phagocytosis through the activation and phosphorylation of Wiskott-Aldrich syndrome protein (WASP) and neural-WASP, Mol Biol Cell 20 (2009), 4500-4508.

[59] E. Torres and M.K. Rosen, Contingent phosphorylation/dephosphorylation provides a mechanism of molecular memory in WASP, Mol Cell 11 (2003), 1215-1227.

[60] K. Badour, J. Zhang, F. Shi, Y. Leng, M. Collins and K.A. Siminovitch, Fyn and PTP-PEST-mediated Regulation of Wiskott-Aldrich Syndrome Protein (WASp) Tyrosine Phosphorylation Is Required for Coupling T Cell Antigen Receptor Engagement to WASp Effector Function and T Cell Activation, J Exp Med 199 (2004), 99-112.

[61] J.L. Cannon, C.M. Labno, G. Bosco, A. Seth, M.H. McGavin, K.A. Siminovitch, M.K. Rosen and J.K. Burkhardt, Wasp recruitment to the T cell:APC contact site occurs independently of Cdc42 activation, Immunity 15 (2001), 249-259.

[62] G.O. Cory, R. Garg, R. Cramer and A.J. Ridley, Phosphorylation of tyrosine 291 enhances the ability of WASp to stimulate actin polymerization and filopodium formation. WiskottAldrich Syndrome protein, J Biol Chem 277 (2002), 4511545121.

[63] M.M. Miller, S. Lapetina, S.M. MacGrath, M.K. Sfakianos, T.D. Pollard and A.J. Koleske, Regulation of actin polymerization and adhesion-dependent cell edge protrusion by the Abl-related gene (Arg) tyrosine kinase and N-WASp, Biochemistry 49 (2010), 2227-2234. 
[64] D.A. Adamovich, F. Nakamura, A. Worth, S. Burns, A.J. Thrasher, J.H. Hartwig and S.B. Snapper, Activating mutations of N-WASP alter Shigella pathogenesis, Biochem Biophys Res Commun 384 (2009), 284-289.

[65] F. Castellano, C. Le Clainche, D. Patin, M.F. Carlier and P. Chavrier, A WASp-VASP complex regulates actin polymerization at the plasma membrane, EMBO J 20 (2001), 56035614.

[66] D. Yarar, J.A. D'Alessio, R.L. Jeng and M.D. Welch, Motility Determinants in WASP Family Proteins, Mol Biol Cell 13 (2002), 4045-4059.

[67] Y. Baba, S. Nonoyama, M. Matsushita, T. Yamadori, S. Hashimoto, K. Imai, S. Arai, T. Kunikata, M. Kurimoto, T. Kurosaki, H.D. Ochs, J. Yata, T. Kishimoto and S. Tsuka$\mathrm{da}$, Involvement of wiskott-aldrich syndrome protein in Bcell cytoplasmic tyrosine kinase pathway, Blood 93 (1999), 2003-2012.

[68] S. Banin, I. Gout and P. Brickell, Interaction between Wiskott-Aldrich Syndrome protein (WASP) and the Fyn protein-tyrosine kinase, Mol Biol Rep 26 (1999), 173-177.

[69] S. Banin, O. Truong, D.R. Katz, M.D. Waterfield, P.M. Brickell and I. Gout, Wiskott-Aldrich syndrome protein (WASp) is a binding partner for c-Src family protein-tyrosine kinases, Curr Biol 6 (1996), 981-988.

[70] G.O. Cory, L. MacCarthy-Morrogh, S. Banin, I. Gout, P.M. Brickell, R.J. Levinsky, C. Kinnon and R.C. Lovering, Evidence that the Wiskott-Aldrich syndrome protein may be involved in lymphoid cell signaling pathways, J Immunol 157 (1996), 3791-3795.

[71] B.S. Gross, J.I. Wilde, L. Quek, H. Chapel, D.L. Nelson and S.P. Watson, Regulation and function of WASp in platelets by the collagen receptor, glycoprotein VI, Blood 94 (1999), 4166-4176.

[72] R. Guinamard, P. Aspenstrom, M. Fougereau, P. Chavrier and J.C. Guillemot, Tyrosine phosphorylation of the WiskottAldrich syndrome protein by Lyn and Btk is regulated by CDC42, FEBS Lett 434 (1998), 431-436.

[73] O.M. Rivero-Lezcano, A. Marcilla, J.H. Sameshima and K.C. Robbins, Wiskott-Aldrich syndrome protein physically associates with Nck through Src homology 3 domains, Mol Cell Biol 15 (1995), 5725-5731.

[74] M.P. Scott, F. Zappacosta, E.Y. Kim, R.S. Annan and W.T. Miller, Identification of novel SH3 domain ligands for the Src family kinase Hck. Wiskott-Aldrich syndrome protein (WASP), WASP-interacting protein (WIP), and ELMO1, $J$ Biol Chem 277 (2002), 28238-28246.

[75] H.Y. She, S. Rockow, J. Tang, R. Nishimura, E.Y. Skolnik, M. Chen, B. Margolis and W. Li, Wiskott-Aldrich syndrome protein is associated with the adapter protein Grb2 and the epidermal growth factor receptor in living cells, Mol Biol Cell 8 (1997), 1709-1721.

[76] S. Benesch, S. Lommel, A. Steffen, T.E. Stradal, N. Scaplehorn, M. Way, J. Wehland and K. Rottner, Phosphatidylinositol 4,5-biphosphate (PIP2)-induced vesicle movement depends on N-WASP and involves Nck, WIP, and Grb2, J Biol Chem 277 (2002), 37771-37776.

[77] M.F. Carlier, P. Nioche, I. Broutin-L'Hermite, R. Boujemaa, C. Le Clainche, C. Egile, C. Garbay, A. Ducruix, P. Sansonetti and D. Pantaloni, GRB2 links signaling to actin assembly by enhancing interaction of neural Wiskott-Aldrich syndrome protein (N-WASp) with actin-related protein (ARP2/3) complex, J Biol Chem 275 (2000), 21946-21952.

[78] R. Rohatgi, P. Nollau, H.Y. Ho, M.W. Kirschner and B.J. Mayer, Nck and phosphatidylinositol 4,5-bisphosphate syn- ergistically activate actin polymerization through the $\mathrm{N}$ WASP-Arp2/3 pathway, J Biol Chem 276 (2001), 2644826452.

[79] A. Oda, H.D. Ochs, L.A. Lasky, S. Spencer, K. Ozaki, M. Fujihara, M. Handa, K. Ikebuchi and H. Ikeda, CrkL is an adapter for Wiskott-Aldrich syndrome protein and Syk, Blood 97 (2001), 2633-2639.

[80] P.M. Finan, C.J. Soames, L. Wilson, D.L. Nelson, D.M. Stewart, O. Truong, J.J. Hsuan and S. Kellie, Identification of regions of the Wiskott-Aldrich syndrome protein responsible for association with selected Src homology 3 domains, J Biol Chem 271 (1996), 26291-26295.

[81] K. Badour, M.K. McGavin, J. Zhang, S. Freeman, C. Vieira, D. Filipp, M. Julius, G.B. Mills and K.A. Siminovitch, Interaction of the Wiskott-Aldrich syndrome protein with sorting nexin 9 is required for CD28 endocytosis and cosignaling in T cells, Proc Natl Acad Sci U S A 104 (2007), 1593-1598.

[82] J.F. Cote, P.L. Chung, J.F. Theberge, M. Halle, S. Spencer, L.A. Lasky and M.L. Tremblay, PSTPIP is a substrate of PTPPEST and serves as a scaffold guiding PTP-PEST toward a specific dephosphorylation of WASP, J Biol Chem 277 (2002), 2973-2986.

[83] Y. Wu, S.D. Spencer and L.A. Lasky, Tyrosine phosphorylation regulates the $\mathrm{SH} 3$-mediated binding of the Wiskott-Aldrich syndrome protein to PSTPIP, a cytoskeletalassociated protein, J Biol Chem 273 (1998), 5765-5770.

[84] K. Badour, J. Zhang, F. Shi, M.K. McGavin, V. Rampersad, L.A. Hardy, D. Field and K.A. Siminovitch, The WiskottAldrich syndrome protein acts downstream of CD2 and the CD2AP and PSTPIP1 adaptors to promote formation of the immunological synapse, Immunity 18 (2003), 141-154.

[85] S.B. Padrick, H.C. Cheng, A.M. Ismail, S.C. Panchal, L.K. Doolittle, S. Kim, B.M. Skehan, J. Umetani, C.A. Brautigam, J.M. Leong and M.K. Rosen, Hierarchical regulation of WASP/WAVE proteins, Mol Cell 32 (2008), 426-438.

[86] C. Yang, M. Huang, J. DeBiasio, M. Pring, M. Joyce, H. Miki, T. Takenawa and S.H. Zigmond, Profilin enhances Cdc42induced nucleation of actin polymerization, J Cell Biol $\mathbf{1 5 0}$ (2000), 1001-1012.

[87] K.J. Amann and T.D. Pollard, The Arp2/3 complex nucleates actin filament branches from the sides of pre-existing filaments, Nat Cell Biol 3 (2001), 306-310.

[88] L. Blanchoin, K.J. Amann, H.N. Higgs, J.B. Marchand, D.A. Kaiser and T.D. Pollard, Direct observation of dendritic actin filament networks nucleated by Arp2/3 complex and WASP/Scar proteins, Nature 404 (2000), 1007-1011.

[89] R.D. Mullins, J.A. Heuser and T.D. Pollard, The interaction of Arp2/3 complex with actin: nucleation, high affinity pointed end capping, and formation of branching networks of filaments, Proc Natl Acad Sci U S A 95 (1998), 6181-6186.

[90] H. Falet, K.M. Hoffmeister, R. Neujahr, J.E. Italiano, Jr., T.P. Stossel, F.S. Southwick and J.H. Hartwig, Importance of free actin filament barbed ends for Arp2/3 complex function in platelets and fibroblasts, Proc Natl Acad Sci U S A 99 (2002), 16782-16787.

[91] D. Pantaloni, R. Boujemaa, D. Didry, P. Gounon and M.F. Carlier, The Arp2/3 complex branches filament barbed ends: functional antagonism with capping proteins, Nat Cell Biol 2 (2000), 385-391.

[92] L.M. Machesky and R.H. Insall, Scar1 and the related Wiskott-Aldrich syndrome protein, WASP, regulate the actin cytoskeleton through the Arp $2 / 3$ complex, Curr Biol 8 (1998), 1347-1356. 
[93] R. Rohatgi, L. Ma, H. Miki, M. Lopez, T. Kirchhausen, T. Takenawa and M.W. Kirschner, The interaction between N-WASP and the Arp2/3 complex links Cdc42-dependent signals to actin assembly, Cell 97 (1999), 221-231.

[94] S.C. Panchal, D.A. Kaiser, E. Torres, T.D. Pollard and M.K. Rosen, A conserved amphipathic helix in WASP/Scar proteins is essential for activation of Arp2/3 complex, Nat Struct Biol 10 (2003), 591-598.

[95] G.O. Cory, R. Cramer, L. Blanchoin and A.J. Ridley, Phosphorylation of the WASP-VCA domain increases its affinity for the Arp2/3 complex and enhances actin polymerization by WASP, Mol.Cell 11 (2003), 1229-1239.

[96] K. Hufner, H.N. Higgs, T.D. Pollard, C. Jacobi, M. Aepfelbacher and S. Linder, The verprolin-like central (vc) region of Wiskott-Aldrich syndrome protein induces Arp2/3 complexdependent actin nucleation, J Biol Chem 276 (2001), 3576135767.

[97] A.E. Kelly, H. Kranitz, V. Dotsch and R.D. Mullins, Actin binding to the central domain of WASP/Scar proteins plays a critical role in the activation of the Arp2/3 complex, J Biol Chem 281 (2006), 10589-10597.

[98] J.B. Marchand, D.A. Kaiser, T.D. Pollard and H.N. Higgs, Interaction of WASP/Scar proteins with actin and vertebrate Arp2/3 complex, Nat Cell Biol 3 (2001), 76-82.

[99] O. Parolini, S. Berardelli, E. Riedl, C. Bello-Fernandez, H. Strobl, O. Majdic and W. Knapp, Expression of WiskottAldrich syndrome protein (WASP) gene during hematopoietic differentiation, Blood 90 (1997), 70-75.

[100] C. Yan, N. Martinez-Quiles, S. Eden, T. Shibata, F. Takeshima, R. Shinkura, Y. Fujiwara, R. Bronson, S.B. Snapper, M.W. Kirschner, R. Geha, F.S. Rosen and F.W. Alt, WAVE2 deficiency reveals distinct roles in embryogenesis and Racmediated actin-based motility, EMBO J 22 (2003), 36023612 .

[101] S.B. Snapper, F. Takeshima, I. Anton, C.H. Liu, S.M. Thomas, D. Nguyen, D. Dudley, H. Fraser, D. Purich, M. Lopez-Ilasaca, C. Klein, L. Davidson, R. Bronson, R.C. Mulligan, F. Southwick, R. Geha, M.B. Goldberg, F.S. Rosen, J.H. Hartwig and F.W. Alt, N-WASP deficiency reveals distinct pathways for cell surface projections and microbial actin-based motility, Nat Cell Biol 3 (2001), 897-904.

[102] S.H. Soderling, L.K. Langeberg, J.A. Soderling, S.M. Davee, R. Simerly, J. Raber and J.D. Scott, Loss of WAVE-1 causes sensorimotor retardation and reduced learning and memory in mice, Proc Natl Acad Sci U S A 100 (2003), 1723-1728.

[103] W.L. Greer, P.C. Kwong, M. Peacocke, P. Ip, L.A. Rubin and K.A. Siminovitch, X-chromosome inactivation in the Wiskott-Aldrich syndrome: a marker for detection of the carrier state and identification of cell lineages expressing the gene defect, Genomics 4 (1989), 60-67.

[104] H. Inoue, H. Kurosawa, S. Nonoyama, K. Imai, H. Kumazaki, T. Matsunaga, Y. Sato, K. Sugita and M. Eguchi, X-linked thrombocytopenia in a girl, Br J Haematol 118 (2002), 11631165 .

[105] A. Proust, B. Guillet, I. Pellier, P. Rachieru, C. Hoarau, S. Claeyssens, C. Leonard, S. Charrier, W. Vainchenker, G. Tchernia and J. Delaunay, Recurrent V75M mutation within the Wiskott-Aldrich syndrome protein: description of a homozygous female patient, Eur J Haematol 75 (2005), 54-59.

[106] C. Lacout, E. Haddad, S. Sabri, F. Svinarchouk, L. Garcon, C. Capron, A. Foudi, R. Mzali, S.B. Snapper, F. Louache, W. Vainchenker and D. Dumenil, A defect in hematopoietic stem cell migration explains the nonrandom X-chromosome inactivation in carriers of Wiskott-Aldrich syndrome, Blood 102 (2003), 1282-1289.

[107] D.A. Moulding, M.P. Blundell, D.G. Spiller, M.R. White, G.O. Cory, Y. Calle, H. Kempski, J. Sinclair, P.J. Ancliff, C. Kinnon, G.E. Jones and A.J. Thrasher, Unregulated actin polymerization by WASp causes defects of mitosis and cytokinesis in X-linked neutropenia, J.Exp.Med. 204 (2007), 2213-2224.

[108] A. Meyer-Bahlburg, S. Becker-Herman, S. Humblet-Baron, S. Khim, M. Weber, G. Bouma, A.J. Thrasher, F.D. Batista and D.J. Rawlings, Wiskott-Aldrich syndrome protein deficiency in B cells results in impaired peripheral homeostasis, Blood 112 (2008), 4158-4169.

[109] L.S. Westerberg, M.A. de la Fuente, F. Wermeling, H.D. Ochs, M.C. Karlsson, S.B. Snapper and L.D. Notarangelo, WASP confers selective advantage for specific hematopoietic cell populations and serves a unique role in marginal zone B-cell homeostasis and function, Blood 112 (2008), 41394147.

[110] T. Wada, A. Konno, S.H. Schurman, E.K. Garabedian, S.M. Anderson, M. Kirby, D.L. Nelson and F. Candotti, Secondsite mutation in the Wiskott-Aldrich syndrome (WAS) protein gene causes somatic mosaicism in two WAS siblings, $J$ Clin Invest 111 (2003), 1389-1397.

[111] T. Ariga, M. Yamada, T. Wada, S. Saitoh and Y. Sakiyama, Detection of lymphocytes and granulocytes expressing the mutant WASP message in carriers of Wiskott-Aldrich syndrome, Br J Haematol 104 (1999), 893-900.

[112] T. Ariga, T. Kondoh, K. Yamaguchi, M. Yamada, S. Sasaki, D.L. Nelson, H. Ikeda, K. Kobayashi, H. Moriuchi and Y. Sakiyama, Spontaneous in vivo reversion of an inherited mutation in the Wiskott-Aldrich syndrome, J Immunol 166 (2001), 5245-5249.

[113] B.R. Davis and F. Candotti, Revertant somatic mosaicism in the Wiskott-Aldrich syndrome, Immunol Res 44 (2009), 127-131.

[114] B.R. Davis, Q. Yan, J.H. Bui, K. Felix, D. Moratto, L.M. Muul, N.L. Prokopishyn, R.M. Blaese and F. Candotti, Somatic mosaicism in the Wiskott-Aldrich syndrome: molecular and functional characterization of genotypic revertants, Clin Immunol 135 (2010), 72-83.

[115] A. Konno, T. Wada, S.H. Schurman, E.K. Garabedian, M. Kirby, S.M. Anderson and F. Candotti, Differential contribution of Wiskott-Aldrich syndrome protein to selective advantage in T- and B-cell lineages, Blood 103 (2004), 676-678.

[116] S. Trifari, S. Scaramuzza, M. Catucci, M. Ponzoni, L. Mollica, R. Chiesa, F. Cattaneo, F. Lafouresse, R. Calvez, W. Vermi, D. Medicina, M.C. Castiello, F. Marangoni, M. Bosticardo, C. Doglioni, M. Caniglia, A. Aiuti, A. Villa, M.G. Roncarolo and L. Dupre, Revertant T lymphocytes in a patient with Wiskott-Aldrich syndrome: analysis of function and distribution in lymphoid organs, J Allergy Clin Immunol 125 (2010), 439-448 e438.

[117] W. Du, S. Kumaki, T. Uchiyama, A. Yachie, C. Yeng Looi, S. Kawai, M. Minegishi, N. Ramesh, R.S. Geha, Y. Sasahara and S. Tsuchiya, A second-site mutation in the initiation codon of WAS (WASP) results in expansion of subsets of lymphocytes in an Wiskott-Aldrich syndrome patient, Hum Mutat 27 (2006), 370-375.

[118] K. Boztug, M. Germeshausen, I. Avedillo Diez, V. Gulacsy, J. Diestelhorst, M. Ballmaier, K. Welte, L. Marodi, L. Chernyshova and C. Klein, Multiple independent secondsite mutations in two siblings with somatic mosaicism for Wiskott-Aldrich syndrome, Clin Genet 74 (2008), 68-74. 
[119] M.I. Lutskiy, D.S. Beardsley, F.S. Rosen and E. RemoldO'Donnell, Mosaicism of NK cells in a patient with WiskottAldrich syndrome, Blood 106 (2005), 2815-2817.

[120] H.D. Ochs, S.J. Slichter, L.A. Harker, W.E. Von Behrens, R.A. Clark and R.J. Wedgwood, The Wiskott-Aldrich syndrome: studies of lymphocytes, granulocytes, and platelets, Blood 55 (1980), 243-252.

[121] J.Y. Park, M. Kob, A.P. Prodeus, F.S. Rosen, A. Shcherbina and E. Remold-O'Donnell, Early deficit of lymphocytes in Wiskott-Aldrich syndrome: possible role of WASP in human lymphocyte maturation, Clin Exp Immunol 136 (2004), 104110.

[122] S.L. Rawlings, G.M. Crooks, D. Bockstoce, L.W. Barsky, R. Parkman and K.I. Weinberg, Spontaneous apoptosis in lymphocytes from patients with Wiskott-Aldrich syndrome: correlation of accelerated cell death and attenuated bcl-2 expression, Blood 94 (1999), 3872-3882.

[123] D. Kenney, L. Cairns, E. Remold-O'Donnell, J. Peterson, F.S. Rosen and R. Parkman, Morphological abnormalities in the lymphocytes of patients with the Wiskott-Aldrich syndrome, Blood 68 (1986), 1329-1332.

[124] S. Majstoravich, J. Zhang, S. Nicholson-Dykstra, S. Linder, W. Friedrich, K.A. Siminovitch and H.N. Higgs, Lymphocyte microvilli are dynamic, actin-dependent structures that do not require Wiskott-Aldrich syndrome protein (WASp) for their morphology, Blood 104 (2004), 1396-1403.

[125] L. Dupre, A. Aiuti, S. Trifari, S. Martino, P. Saracco, C. Bordignon and M.G. Roncarolo, Wiskott-Aldrich syndrome protein regulates lipid raft dynamics during immunological synapse formation, Immunity 17 (2002), 157-166.

[126] J.L. Cannon and J.K. Burkhardt, Differential roles for Wiskott-Aldrich syndrome protein in immune synapse formation and IL-2 production, The Journal of Immunology 173 (2004), 1658-1662.

[127] T.N. Sims, T.J. Soos, H.S. Xenias, B. Dubin-Thaler, J.M. Hofman, J.C. Waite, T.O. Cameron, V.K. Thomas, R. Varma, C.H. Wiggins, M.P. Sheetz, D.R. Littman and M.L. Dustin, Opposing effects of PKCtheta and WASp on symmetry breaking and relocation of the immunological synapse, Cell 129 (2007), 773-785.

[128] J.E. Ryser, E. Rungger-Brandle, C. Chaponnier, G. Gabbiani and P. Vassalli, The area of attachment of cytotoxic T lymphocytes to their target cells shows high motility and polarization of actin, but not myosin, J Immunol 128 (1982), 1159-1162.

[129] C. Silvin, B. Belisle and A. Abo, A role for Wiskott-Aldrich syndrome protein in T-cell receptor-mediated transcriptional activation independent of actin polymerization, $\mathrm{J}$ Biol Chem 276 (2001), 21450-21457.

[130] V. Cotta-de-Almeida, L. Westerberg, M.H. Maillard, D. Onaldi, H. Wachtel, P. Meelu, U.I. Chung, R. Xavier, F.W. Alt and S.B. Snapper, Wiskott Aldrich syndrome protein (WASP) and N-WASP are critical for T cell development, Proc Natl Acad Sci USA 104 (2007), 15424-15429.

[131] K.D. Fischer, K. Tedford and J.M. Penninger, Vav links antigen-receptor signaling to the actin cytoskeleton, Semin Immunol 10 (1998), 317-327.

[132] N. Foger, L. Rangell, D.M. Danilenko and A.C. Chan, Requirement for coronin 1 in $\mathrm{T}$ lymphocyte trafficking and cellular homeostasis, Science 313 (2006), 839-842.

[133] K.L. Randall, T. Lambe, A.L. Johnson, B. Treanor, E. Kucharska, H. Domaschenz, B. Whittle, L.E. Tze, A. Enders, T.L. Crockford, T. Bouriez-Jones, D. Alston, J.G. Cyster, M.J. Lenardo, F. Mackay, E.K. Deenick, S.G. Tangye, T.D.
Chan, T. Camidge, R. Brink, C.G. Vinuesa, F.D. Batista, R.J. Cornall and C.C. Goodnow, Dock8 mutations cripple B cell immunological synapses, germinal centers and long-lived antibody production, Nat Immunol 10 (2009), 1283-1291.

[134] Q. Zhang, J.C. Davis, I.T. Lamborn, A.F. Freeman, H. Jing, A.J. Favreau, H.F. Matthews, J. Davis, M.L. Turner, G. Uzel, S.M. Holland and H.C. Su, Combined immunodeficiency associated with DOCK8 mutations, NEngl J Med 361 (2009), 2046-2055.

[135] M.H. Maillard, V. Cotta-de-Almeida, F. Takeshima, D.D. Nguyen, P. Michetti, C. Nagler, A.K. Bhan and S.B. Snapper, The Wiskott-Aldrich syndrome protein is required for the function of CD4(+)CD25(+)Foxp3(+) regulatory T cells, $J$ Exp Med 204 (2007), 381-391.

[136] S. Humblet-Baron, B. Sather, S. Anover, S. Becker-Herman, D.J. Kasprowicz, S. Khim, T. Nguyen, K. Hudkins-Loya, C.E. Alpers, S.F. Ziegler, H. Ochs, T. Torgerson, D.J. Campbell and D.J. Rawlings, Wiskott-Aldrich syndrome protein is required for regulatory $\mathrm{T}$ cell homeostasis, J Clin Invest $\mathbf{1 1 7}$ (2007), 407-418.

[137] F. Marangoni, S. Trifari, S. Scaramuzza, C. Panaroni, S. Martino, L.D. Notarangelo, Z. Baz, A. Metin, F. Cattaneo, A. Villa, A. Aiuti, M. Battaglia, M.G. Roncarolo and L. Dupre, WASP regulates suppressor activity of human and murine CD4(+)CD25(+)FOXP3(+) natural regulatory T cells, $J$ Exp Med 204 (2007), 369-380.

[138] J. Zhang, A. Shehabeldin, L.A. da Cruz, J. Butler, A.K. Somani, M. McGavin, I. Kozieradzki, A.O. dos Santos, A. Nagy, S. Grinstein, J.M. Penninger and K.A. Siminovitch, Antigen receptor-induced activation and cytoskeletal rearrangement are impaired in Wiskott-Aldrich syndrome protein-deficient lymphocytes, J Exp Med 190 (1999), 13291342

[139] S.B. Snapper, F.S. Rosen, E. Mizoguchi, P. Cohen, W. Khan, C.H. Liu, T.L. Hagemann, S.P. Kwan, R. Ferrini, L. Davidson, A.K. Bhan and F.W. Alt, Wiskott-Aldrich syndrome protein-deficient mice reveal a role for WASP in T but not B cell activation, Immunity 9 (1998), 81-91.

[140] K.E. Sullivan, C.A. Mullen, R.M. Blaese and J.A. Winkelstein, A multiinstitutional survey of the Wiskott-Aldrich syndrome, J Pediatr. 125 (1994), 876-885.

[141] H.U. Simon, G.B. Mills, S. Hashimoto and K.A. Siminovitch, Evidence for defective transmembrane signaling in B cells from patients with Wiskott-Aldrich syndrome, J Clin Invest 90 (1992), 1396-1405.

[142] F. Facchetti, L. Blanzuoli, W. Vermi, L.D. Notarangelo, S. Giliani, M. Fiorini, A. Fasth, D.M. Stewart and D.L. Nelson, Defective actin polymerization in EBV-transformed B-cell lines from patients with the Wiskott-Aldrich syndrome, $J$ Pathol 185 (1998), 99-107.

[143] L. Westerberg, G. Greicius, S.B. Snapper, P. Aspenstrom and E. Severinson, Cdc42, Rac1, and the Wiskott-Aldrich syndrome protein are involved in the cytoskeletal regulation of B lymphocytes, Blood 98 (2001), 1086-1094.

[144] L. Westerberg, M. Larsson, S.J. Hardy, C. Fernandez, A.J. Thrasher and E. Severinson, Wiskott-Aldrich syndrome protein deficiency leads to reduced B-cell adhesion, migration, and homing, and a delayed humoral immune response, Blood 105 (2005), 1144-1152.

[145] N. Andreu, J.M. Aran and C. Fillat, Novel membrane cell projection defects in Wiskott-Aldrich syndrome B cells, Int J Mol Med 20 (2007), 445-450.

[146] W. Vermi, L. Blanzuoli, M.D. Kraus, P. Grigolato, F. Donato, G. Loffredo, C.E. Marino, D. Alberti, L.D. Notarangelo and 
F. Facchetti, The spleen in the Wiskott-Aldrich syndrome: histopathologic abnormalities of the white pulp correlate with the clinical phenotype of the disease, Am J Surg Pathol $\mathbf{2 3}$ (1999), 182-191.

[147] S. de Noronha, S. Hardy, J. Sinclair, M.P. Blundell, J. Strid, O. Schulz, J. Zwirner, G.E. Jones, D.R. Katz, C. Kinnon and A.J. Thrasher, Impaired dendritic-cell homing in vivo in the absence of Wiskott-Aldrich syndrome protein, Blood 105 (2005), 1590-1597.

[148] L.L. Lanier, Evolutionary struggles between NK cells and viruses, Nat Rev Immunol 8 (2008), 259-268.

[149] C.A. Biron, Activation and function of natural killer cell responses during viral infections, Curr Opin Immunol 9 (1997), 24-34.

[150] J.S. Orange, N. Ramesh, E. Remold-O'Donnell, Y. Sasahara, L. Koopman, M. Byrne, F.A. Bonilla, F.S. Rosen, R.S. Geha and J.L. Strominger, Wiskott-Aldrich syndrome protein is required for NK cell cytotoxicity and colocalizes with actin to NK cell-activating immunologic synapses, Proc Natl Acad Sci USA 99 (2002), 11351-11356.

[151] T. Morio, K. Takase, H. Okawa, M. Oguchi, M. Kanbara, F. Hiruma, K. Yoshino, T. Kaneko, S. Asamura and T. Inoue, The increase of non-MHC-restricted cytotoxic cells (gamma/delta-TCR-bearing T cells or NK cells) and the abnormal differentiation of $\mathrm{B}$ cells in Wiskott-Aldrich syndrome, Clin Immunol Immunopathol 52 (1989), 279-290.

[152] A. Gismondi, L. Cifaldi, C. Mazza, S. Giliani, S. Parolini, S. Morrone, J. Jacobelli, E. Bandiera, L. Notarangelo and A. Santoni, Impaired natural and CD16-mediated NK cell cytotoxicity in patients with WAS and XLT: ability of IL2 to correct NK cell functional defect, Blood 104 (2004), $436-443$

[153] W. Huang, H.D. Ochs, B. Dupont and Y.M. Vyas, The Wiskott-Aldrich syndrome protein regulates nuclear translocation of NFAT2 and NF-kappa B (RelA) independently of its role in filamentous actin polymerization and actin cytoskeletal rearrangement, J Immunol 174 (2005), 2602-2611.

[154] H. Stabile, C. Carlino, C. Mazza, S. Giliani, S. Morrone, L.D. Notarangelo, A. Santoni and A. Gismondi, Impaired NKcell migration in WAS/XLT patients: role of Cdc42/WASp pathway in the control of chemokine-induced beta2 integrin high-affinity state, Blood 115 (2010), 2818-2826.

[155] J.A. Berzofsky and M. Terabe, The contrasting roles of NKT cells in tumor immunity, Curr Mol Med 9 (2009), 667-672.

[156] M. Locci, E. Draghici, F. Marangoni, M. Bosticardo, M. Catucci, A. Aiuti, C. Cancrini, L. Marodi, T. Espanol, R.G. Bredius, A.J. Thrasher, A. Schulz, J. Litzman, M.G. Roncarolo, G. Casorati, P. Dellabona and A. Villa, The WiskottAldrich syndrome protein is required for iNKT cell maturation and function, J Exp Med 206 (2009), 735-742.

[157] A. Astrakhan, H.D. Ochs and D.J. Rawlings, Wiskott-Aldrich syndrome protein is required for homeostasis and function of invariant NKT cells, J Immunol 182 (2009), 7370-7380.

[158] R. Badolato, S. Sozzani, F. Malacarne, S. Bresciani, M. Fiorini, A. Borsatti, A. Albertini, A. Mantovani, A.G. Ugazio and L.D. Notarangelo, Monocytes from Wiskott-Aldrich Patients Display Reduced Chemotaxis and Lack of Cell Polarization in Response to Monocyte Chemoattractant Protein-1 and Formyl-Methionyl-Leucyl-Phenylalanine, The Journal of Immunology 161 (1998), 1026-1033.

[159] D. Zicha, W.E. Allen, P.M. Brickell, C. Kinnon, G.A. Dunn, G.E. Jones and A.J. Thrasher, Chemotaxis of macrophages is abolished in the Wiskott-Aldrich syndrome, Br J Haematol 101 (1998), 659-665.
[160] M. Binks, G.E. Jones, P.M. Brickell, C. Kinnon, D.R. Katz and A.J. Thrasher, Intrinsic dendritic cell abnormalities in Wiskott-Aldrich syndrome, Eur J Immunol 28 (1998), 32593267.

[161] G. Bouma, S. Burns and A.J. Thrasher, Impaired T cell priming in vivo resulting from dysfunction of WASp-deficient dendritic cells, Blood 110 (2007), 4278-4284.

[162] H. Zhang, U.Y. Schaff, C.E. Green, H. Chen, M.R. Sarantos, Y. Hu, D. Wara, S.I. Simon and C.A. Lowell, Impaired integrin-dependent function in Wiskott-Aldrich syndrome protein-deficient murine and human neutrophils, Immunity 25 (2006), 285-295.

[163] J. Pulecio, E. Tagliani, A. Scholer, F. Prete, L. Fetler, O.R. Burrone and F. Benvenuti, Expression of Wiskott-Aldrich syndrome protein in dendritic cells regulates synapse formation and activation of naive CD8+ T cells, J Immunol $\mathbf{1 8 1}$ (2008), 1135-1142.

[164] J.M. Delaisse, M.T. Engsig, V. Everts, M. del Carmen Ovejero, M. Ferreras, L. Lund, T.H. Vu, Z. Werb, B. Winding, A. Lochter, M.A. Karsdal, T. Troen, T. Kirkegaard, T. Lenhard, A.M. Heegaard, L. Neff, R. Baron and N.T. Foged, Proteinases in bone resorption: obvious and less obvious roles, Clin Chim Acta 291 (2000), 223-234.

[165] G. Burgstaller and M. Gimona, Podosome-mediated matrix resorption and cell motility in vascular smooth muscle cells, Am J Physiol Heart Circ Physiol 288 (2005), H3001-3005.

[166] P.C. Marchisio, D. Cirillo, L. Naldini, M.V. Primavera, A. Teti and A. Zambonin-Zallone, Cell-substratum interaction of cultured avian osteoclasts is mediated by specific adhesion structures, J Cell Biol 99 (1984), 1696-1705.

[167] A. Olivier, L. Jeanson-Leh, G. Bouma, D. Compagno, J. Blondeau, K. Seye, S. Charrier, S. Burns, A.J. Thrasher, O. Danos, W. Vainchenker and A. Galy, A partial downregulation of WASP is sufficient to inhibit podosome formation in dendritic cells, Mol Ther 13 (2006), 729-737.

[168] S. Linder, D. Nelson, M. Weiss and M. Aepfelbacher, Wiskott-Aldrich syndrome protein regulates podosomes in primary human macrophages, Proc Natl Acad Sci USA 96 (1999), 9648-9653.

[169] S. Burns, A.J. Thrasher, M.P. Blundell, L. Machesky and G.E. Jones, Configuration of human dendritic cell cytoskeleton by Rho GTPases, the WAS protein, and differentiation, Blood 98 (2001), 1142-1149.

[170] Y. Calle, G.E. Jones, C. Jagger, K. Fuller, M.P. Blundell, J. Chow, T. Chambers and A.J. Thrasher, WASp deficiency in mice results in failure to form osteoclast sealing zones and defects in bone resorption, Blood 103 (2004), 3552-3561.

[171] S. Burns, S.J. Hardy, J. Buddle, K.L. Yong, G.E. Jones and A.J. Thrasher, Maturation of DC is associated with changes in motile characteristics and adherence, Cell Motil.Cytoskeleton 57 (2004), 118-132.

[172] S. Tsuboi, H. Takada, T. Hara, N. Mochizuki, T. Funyu, H. Saitoh, Y. Terayama, K. Yamaya, C. Ohyama, S. Nonoyama and H.D. Ochs, FBP17 Mediates a Common Molecular Step in the Formation of Podosomes and Phagocytic Cups in Macrophages, J Biol Chem 284 (2009), 8548-8556.

[173] Y. Calle, N.O. Carragher, A.J. Thrasher and G.E. Jones, Inhibition of calpain stabilises podosomes and impairs dendritic cell motility, J Cell Sci 119 (2006), 2375-2385.

[174] A. Dovas, J.C. Gevrey, A. Grossi, H. Park, W. AbouKheir and D. Cox, Regulation of podosome dynamics by WASp phosphorylation: implication in matrix degradation and chemotaxis in macrophages, J Cell Sci 122 (2009), 38733882 . 
[175] W.E. Allen, G.E. Jones, J.W. Pollard and A.J. Ridley, Rho, Rac and Cdc42 regulate actin organization and cell adhesion in macrophages, J Cell Sci 110(Pt 6) (1997), 707-720.

[176] W.E. Allen, D. Zicha, A.J. Ridley and G.E. Jones, A role for Cdc42 in macrophage chemotaxis, J Cell Biol 141 (1998), $1147-1157$.

[177] D. Yarar, W. To, A. Abo and M.D. Welch, The WiskottAldrich syndrome protein directs actin-based motility by stimulating actin nucleation with the Arp2/3 complex, Curr Biol 9 (1999), 555-558

[178] G.E. Jones, D. Zicha, G.A. Dunn, M. Blundell and A. Thrasher, Restoration of podosomes and chemotaxis in WiskottAldrich syndrome macrophages following induced expression of WASp, Int J Biochem Cell Biol 34 (2002), 806-815.

[179] S. Charrier, D. Stockholm, K. Seye, P. Opolon, M. Taveau, D.A. Gross, S. Bucher-Laurent, C. Delenda, W. Vainchenker, O. Danos and A. Galy, A lentiviral vector encoding the human Wiskott-Aldrich syndrome protein corrects immune and cytoskeletal defects in WASP knockout mice, Gene Ther 12 (2005), 597-606.

[180] M.P. Blundell, G. Bouma, Y. Calle, G.E. Jones, C. Kinnon and A.J. Thrasher, Improvement of migratory defects in a murine model of Wiskott-Aldrich syndrome gene therapy, Mol Ther 16 (2008), 836-844.

[181] R. Lorenzi, P.M. Brickell, D.R. Katz, C. Kinnon and A.J. Thrasher, Wiskott-Aldrich syndrome protein is necessary for efficient IgG-mediated phagocytosis, Blood 95 (2000), 29432946.

[182] Y. Leverrier, R. Lorenzi, M.P. Blundell, P. Brickell, C. Kinnon, A.J. Ridley and A.J. Thrasher, Cutting edge: the Wiskott-Aldrich syndrome protein is required for efficient phagocytosis of apoptotic cells, The Journal of Immunology 166 (2001), 4831-4834.

[183] E. Haddad, E. Cramer, C. Riviere, P. Rameau, F. Louache, J. Guichard, D.L. Nelson, A. Fischer, W. Vainchenker and N. Debili, The thrombocytopenia of Wiskott Aldrich syndrome is not related to a defect in proplatelet formation, Blood $\mathbf{9 4}$ (1999), 509-518.

[184] B.M. Marathe, A. Prislovsky, A. Astrakhan, D.J. Rawlings, J.Y. Wan and T.S. Strom, Antiplatelet antibodies in WASP() mice correlate with evidence of increased in vivo platelet consumption, Exp Hematol 37 (2009), 1353-1363.

[185] S. Sabri, A. Foudi, S. Boukour, B. Franc, S. Charrier, M. Jandrot-Perrus, R.W. Farndale, A. Jalil, M.P. Blundell, E.M. Cramer, F. Louache, N. Debili, A.J. Thrasher and W. Vainchenker, Deficiency in the Wiskott-Aldrich protein induces premature proplatelet formation and platelet production in the bone marrow compartment, Blood 108 (2006), 134-140.

[186] S.H. Schurman and F. Candotti, Autoimmunity in WiskottAldrich syndrome, Curr Opin Rheumatol 15 (2003), 446453.

[187] H. Ozsahin, M. Cavazzana-Calvo, L.D. Notarangelo, A. Schulz, A.J. Thrasher, E. Mazzolari, M.A. Slatter, F. Le Deist, S. Blanche, P. Veys, A. Fasth, R. Bredius, P. Sedlacek, N. Wulffraat, J. Ortega, C. Heilmann, A. O'Meara, J. Wachowiak, K. Kalwak, S. Matthes-Martin, T. Gungor, A. Ikinciogullari, P. Landais, A.J. Cant, W. Friedrich and A. Fischer, Long-term outcome following hematopoietic stemcell transplantation in Wiskott-Aldrich syndrome: collaborative study of the European Society for Immunodeficiencies and European Group for Blood and Marrow Transplantation, Blood 111 (2008), 439-445.
[188] S. Dupuis-Girod, J. Medioni, E. Haddad, P. Quartier, M. Cavazzana-Calvo, F. Le Deist, B.G. de Saint, J. Delaunay, K. Schwarz, J.L. Casanova, S. Blanche and A. Fischer, Autoimmunity in Wiskott-Aldrich syndrome: risk factors, clinical features, and outcome in a single-center cohort of 55 patients, Pediatrics 111 (2003), e622-e627.

[189] D.D. Nguyen, M.H. Maillard, V. Cotta-de-Almeida, E. Mizoguchi, C. Klein, I. Fuss, C. Nagler, A. Mizoguchi, A.K. Bhan and S.B. Snapper, Lymphocyte-dependent and Th2 cytokine-associated colitis in mice deficient in WiskottAldrich syndrome protein, Gastroenterology 133 (2007), 1188-1197.

[190] R.M. Siegel, F.K. Chan, H.J. Chun and M.J. Lenardo, The multifaceted role of Fas signaling in immune cell homeostasis and autoimmunity, Nat Immunol 1 (2000), 469-474.

[191] N.P. Nikolov, M. Shimizu, S. Cleland, D. Bailey, J. Aoki, T. Strom, P.L. Schwartzberg, F. Candotti and R.M. Siegel, Systemic autoimmunity and defective Fas ligand secretion in the absence of the Wiskott-Aldrich syndrome protein, Blood (2010), published online May 10.

[192] P.R. Taylor, A. Carugati, V.A. Fadok, H.T. Cook, M. Andrews, M.C. Carroll, J.S. Savill, P.M. Henson, M. Botto and M.J. Walport, A hierarchical role for classical pathway complement proteins in the clearance of apoptotic cells in vivo, $J$ Exp Med 192 (2000), 359-366.

[193] C.C. Goodnow, Multistep pathogenesis of autoimmune disease, Cell 130 (2007), 25-35.

[194] C. Schuetz, T. Niehues, W. Friedrich and K. Schwarz, Autoimmunity, autoinflammation and lymphoma in combined immunodeficiency (CID), Autoimmun Rev 9 (2010), 477482.

[195] R. Parkman, Treatment of immunodeficiency diseases by organ transplantation, Prog Clin Immunol 3 (1977), 85-102.

[196] I.J. Rimm and J.M. Rappeport, Bone marrow transplantation for the Wiskott-Aldrich syndrome. Long-term follow-up, Transplantation 50 (1990), 617-620.

[197] J.A. Brochstein, A.P. Gillio, M. Ruggiero, N.A. Kernan, D. Emanuel, J. Laver, T. Small and R.J. O’Reilly, Marrow transplantation from human leukocyte antigen-identical or haploidentical donors for correction of Wiskott-Aldrich syndrome, J Pediatr 119 (1991), 907-912.

[198] M.E. Conley, D. Saragoussi, L. Notarangelo, A. Etzioni and J.L. Casanova, An international study examining therapeutic options used in treatment of Wiskott-Aldrich syndrome, Clin.Immunol. 109 (2003), 272-277.

[199] P. Satwani, E. Morris, M.B. Bradley, M. Bhatia, C. van de Ven and M.S. Cairo, Reduced intensity and non-myeloablative allogeneic stem cell transplantation in children and adolescents with malignant and non-malignant diseases, Pediatr Blood Cancer 50 (2008), 1-8.

[200] W. Qasim, M. Cavazzana-Calvo, E.G. Davies, J. Davis, M. Duval, G. Eames, N. Farinha, A. Filopovich, A. Fischer, W. Friedrich, A. Gennery, C. Heilmann, P. Landais, M. Horwitz, F. Porta, P. Sedlacek, R. Seger, M. Slatter, L. Teague, M. Eapen and P. Veys, Allogeneic hematopoietic stem-cell transplantation for leukocyte adhesion deficiency, Pediatrics 123 (2009), 836-840.

[201] F. Candotti, F. Facchetti, L. Blanzuoli, D.M. Stewart, D.L. Nelson and R.M. Blaese, Retrovirus-mediated WASP gene transfer corrects defective actin polymerization in B cell lines from Wiskott-Aldrich syndrome patients carrying 'null' mutations, Gene Ther 6 (1999), 1170-1174.

[202] T. Wada, G.J. Jagadeesh, D.L. Nelson and F. Candotti, Retrovirus-mediated WASP gene transfer corrects Wiskott- 
Aldrich syndrome T-cell dysfunction, Hum Gene Ther 13 (2002), 1039-1046.

[203] T.S. Strom, W. Gabbard, P.F. Kelly, J.M. Cunningham and A.W. Nienhuis, Functional correction of T cells derived from patients with the Wiskott-Aldrich syndrome (WAS) by transduction with an oncoretroviral vector encoding the WAS protein, Gene Ther 10 (2003), 803-809.

[204] L. Dupre, S. Trifari, A. Follenzi, F. Marangoni, d.L. Lain, A. Bernad, S. Martino, S. Tsuchiya, C. Bordignon, L. Naldini, A. Aiuti and M.G. Roncarolo, Lentiviral vector-mediated gene transfer in T cells from Wiskott-Aldrich syndrome patients leads to functional correction, Mol Ther 10 (2004), 903-915.

[205] T.S. Strom, S.J. Turner, S. Andreansky, H. Liu, P.C. Doherty, D.K. Srivastava, J.M. Cunningham and A.W. Nienhuis, Defects in T-cell-mediated immunity to influenza virus in murine Wiskott-Aldrich syndrome are corrected by oncoretroviral vector-mediated gene transfer into repopulating hematopoietic cells, Blood 102 (2003), 3108-3116.

[206] L. Dupre, F. Marangoni, S. Scaramuzza, S. Trifari, R.J. Hernandez, A. Aiuti, L. Naldini and M.G. Roncarolo, Efficacy of gene therapy for Wiskott-Aldrich syndrome using a WAS promoter/cDNA-containing lentiviral vector and nonlethal irradiation, Hum Gene Ther 17 (2006), 303-313.

[207] F. Marangoni, M. Bosticardo, S. Charrier, E. Draghici, M. Locci, S. Scaramuzza, C. Panaroni, M. Ponzoni, F. Sanvito, C. Doglioni, M. Liabeuf, B. Gjata, M. Montus, K. Siminovitch, A. Aiuti, L. Naldini, L. Dupre, M.G. Roncarolo, A. Galy and A. Villa, Evidence for long-term efficacy and safety of gene therapy for Wiskott-Aldrich syndrome in preclinical models, Mol Ther 17 (2009), 1073-1082.

[208] S. Charrier, L. Dupre, S. Scaramuzza, L. Jeanson-Leh, M.P. Blundell, O. Danos, F. Cattaneo, A. Aiuti, R. Eckenberg, A.J. Thrasher, M.G. Roncarolo and A. Galy, Lentiviral vectors targeting WASp expression to hematopoietic cells, efficiently transduce and correct cells from WAS patients, Gene Ther 14 (2007), 415-428.

[209] C. Frecha, M.G. Toscano, C. Costa, M.J. Saez-Lara, F.L. Cosset, E. Verhoeyen and F. Martin, Improved lentiviral vectors for Wiskott-Aldrich syndrome gene therapy mimic endogenous expression profiles throughout haematopoiesis, Gene Ther 15 (2008), 930-941.

[210] F. Martin, M.G. Toscano, M. Blundell, C. Frecha, G.K. Srivastava, M. Santamaria, A.J. Thrasher and I.J. Molina, Lentiviral vectors transcriptionally targeted to hematopoietic cells by WASP gene proximal promoter sequences, Gene Ther 12 (2005), 715-723.

[211] M.A. Chellaiah, D. Kuppuswamy, L. Lasky and S. Linder, Phosphorylation of a Wiscott-Aldrich syndrome proteinassociated signal complex is critical in osteoclast bone resorption, J Biol Chem 282 (2007), 10104-10116.

[212] S.C. Bunnell, P.A. Henry, R. Kolluri, T. Kirchhausen, R.J. Rickles and L.J. Berg, Identification of Itk/Tsk Src homology 3 domain ligands, J Biol Chem 271 (1996), 25646-25656.

[213] N. Martinez-Quiles, H.Y. Ho, M.W. Kirschner, N. Ramesh and R.S. Geha, Erk/Src phosphorylation of cortactin acts as a switch on-switch off mechanism that controls its ability to activate N-WASP, Mol Cell Biol 24 (2004), 5269-5280. 


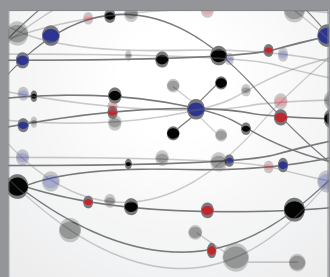

The Scientific World Journal
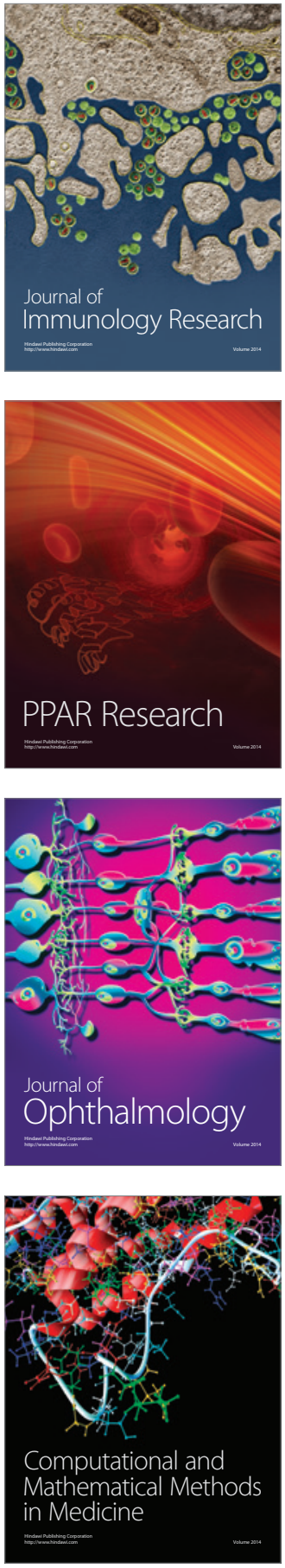

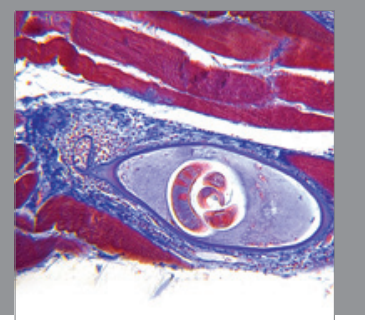

Gastroenterology

Research and Practice
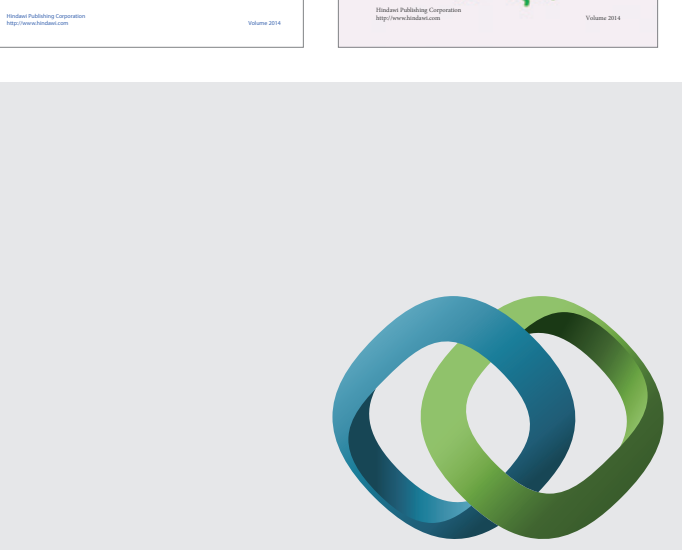

\section{Hindawi}

Submit your manuscripts at

http://www.hindawi.com
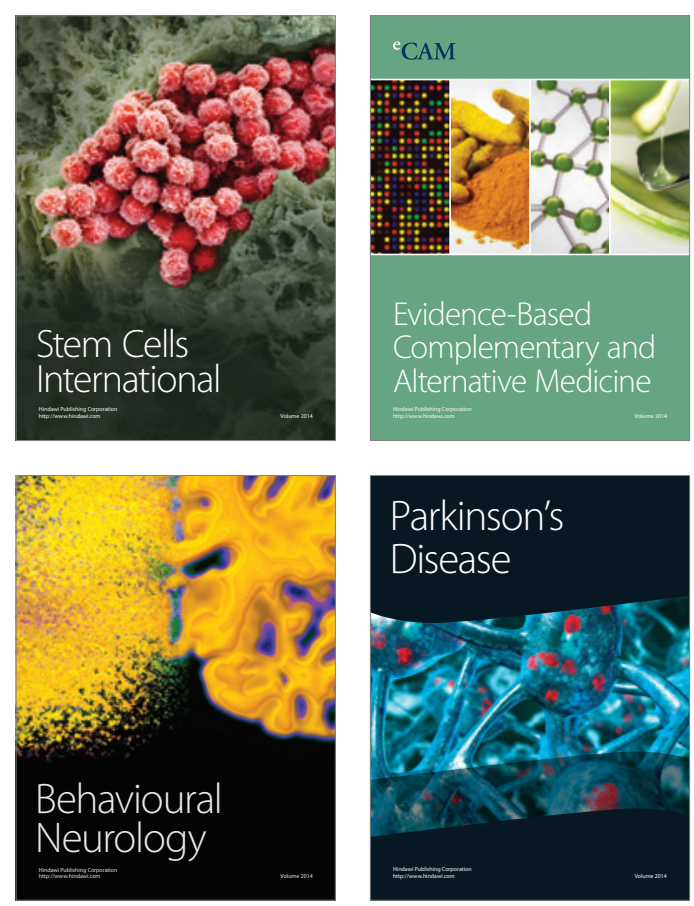

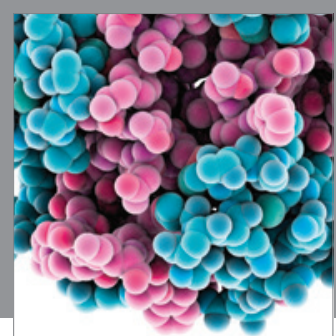

Journal of
Diabetes Research

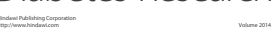

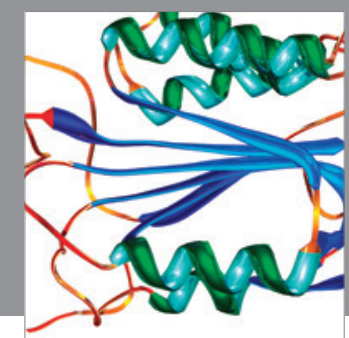

Disease Markers
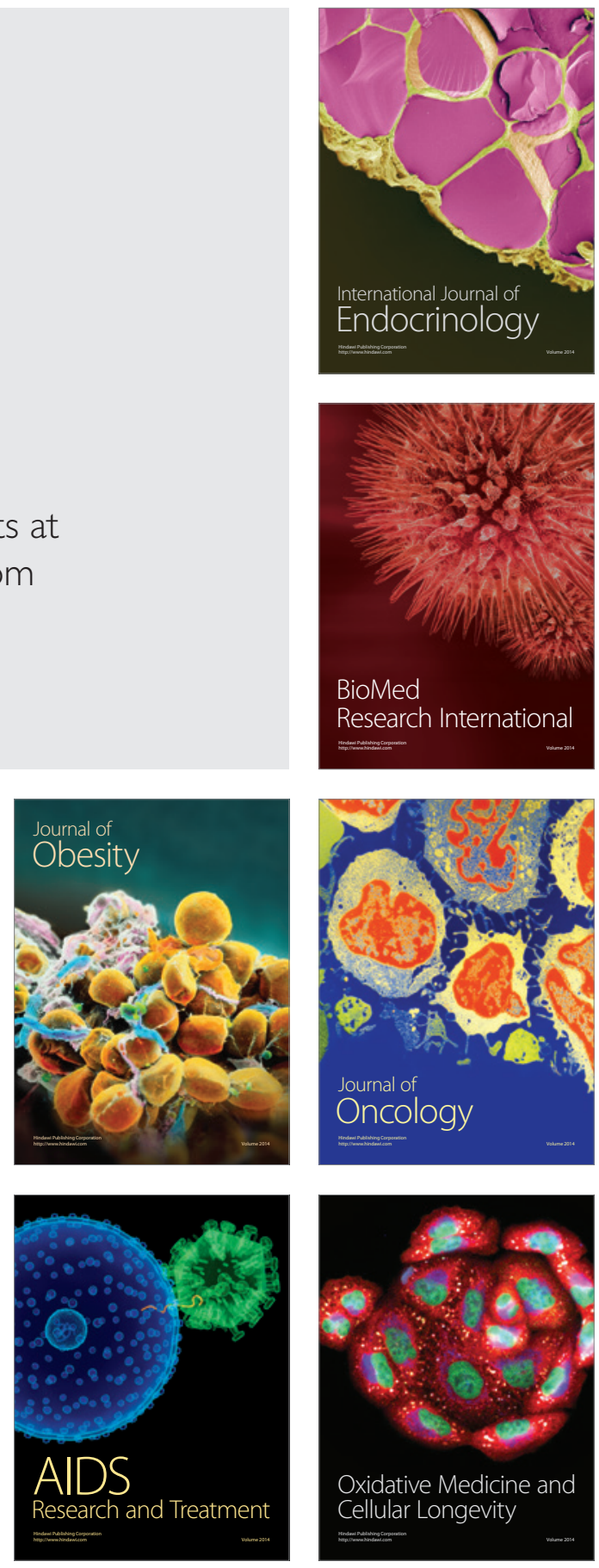